\title{
Isoform-Specific Role of Akt in Oral Squamous Cell Carcinoma
}

\author{
Nand Kishor Roy ${ }^{1}$, Javadi Monisha ${ }^{1}$, Ganesan Padmavathi ${ }^{1}$, H. Lalhruaitluanga ${ }^{2}$, \\ Nachimuthu Senthil Kumar ${ }^{2}$, Anuj Kumar Singh ${ }^{1}$, Devivasha Bordoloi ${ }^{1}$, \\ Munindra Narayan Baruah ${ }^{3}$, Gazi Naseem Ahmed ${ }^{3}$, Imliwati Longkumar ${ }^{3}$, Frank Arfuso ${ }^{4}$, \\ Alan Prem Kumar ${ }^{5,6,7,8} \mathbb{D}$ and Ajaikumar B. Kunnumakkara ${ }^{1, *}$ \\ 1 Cancer Biology Laboratory \& DBT-AIST International Laboratory for Advanced Biomedicine (DAILAB), \\ Department of Biosciences and Bioengineering, Indian Institute of Technology Guwahati, Guwahati 781039, \\ Assam, India \\ 2 Department of Biotechnology, Mizoram University, Aizawl 796 004, Mizoram, India \\ 3 North-East Cancer Hospital and Research Institute, Guwahati 781023, Assam, India \\ 4 Stem Cell and Cancer Biology Laboratory, School of Pharmacy and Biomedical Sciences, Curtin Health \\ Innovation Research Institute, Curtin University, Perth, WA 6009, Australia \\ 5 Department of Pharmacology, Yong Loo Lin School of Medicine, National University of Singapore, \\ Singapore 117600 , Singapore \\ 6 Cancer Science Institute of Singapore, National University of Singapore, Singapore 117599, Singapore \\ 7 Medical Science Cluster, Yong Loo Lin School of Medicine, National University of Singapore, \\ Singapore 117597, Singapore \\ 8 Medical School, Faculty of Health Sciences, Curtin University, Perth, WA 6845, Australia \\ * Correspondence: kunnumakkara@iitg.ac.in or ajai78@gmail.com; Tel.: +91-361-258-2231 or +91-789-600-5326; \\ Fax: +91-361-258-2249
}

Received: 14 March 2019; Accepted: 22 June 2019; Published: 27 June 2019

Abstract: Protein kinase B (Akt) plays a very significant role in various cancers including oral cancer. However, it has three isoforms (Akt1, Akt2, and Akt3) and they perform distinct functions and even play contrasting roles in different cancers. Therefore, it becomes essential to evaluate the isoform-specific role of Akt in oral cancer. In the present study, an attempt has been made to elucidate the isoform-specific role of Akt in oral cancer. The immunohistochemical analysis of oral cancer tissues showed an overexpression of Akt1 and 2 isoforms but not Akt3. Moreover, the dataset of "The Cancer Genome Atlas" for head and neck cancer has suggested the genetic alterations of Akt1 and 2 tend to be associated with the utmost poor clinical outcome in oral cancer. Further, treatment of oral cancer cells with tobacco and its components such as benzo(a)pyrene and nicotine caused increased mRNA levels of Akt 1 and 2 isoforms and also enhanced the aggressiveness of oral cancer cells in terms of proliferation, and clonogenic and migration potential. Finally, silencing of Akt1 and 2 isoforms caused decreased cell survival and induced cell cycle arrest at the G2/M phase. Akt1/2 silencing also reduced tobacco-induced aggressiveness by decreasing the clonogenic and migration potential of oral cancer cells. Moreover, silencing of Akt1 and 2 isoforms was found to decrease the expression of proteins regulating cancer cell survival and proliferation such as cyclooxygenase-2, B-cell lymphoma 2 (Bcl-2), cyclin D1, and survivin. Thus, the important role of Akt1 and 2 isoforms have been elucidated in oral cancer with in-depth mechanistic analysis.

Keywords: Akt isoforms; oral cancer; tissue microarray; immunohistochemistry; tobacco; knockdown

\section{Introduction}

Oral cancer is one of the most challenging diseases faced by mankind, and regardless of several advances made in the field of oral cancer diagnostics and therapeutics, it remains a global health concern. 
It was responsible for approximately 145,400 deaths worldwide in the year 2012 [1]. Oral cancers are mostly carcinomas (96\%), of which $91 \%$ are squamous cell carcinomas. Variations in the incidence of this cancer are the result of several endogenous and exogenous factors such as tobacco use, alcohol intake, and human papilloma virus (HPV) infection. These factors result in numerous genetic and epigenetic changes that cause genomic instability and tumor development and progression [2-7]. The overall and disease-free survival rates of oral squamous cell carcinoma (OSCC) patients remain unchanged due to high mortality and low cure rate. This is mainly due to the lack of proper diagnostic and therapeutic biomarkers for better diagnosis and prognosis and the lack of effective therapies [8-10]. Therefore, it becomes imperative to focus on those molecular mediators that play a key role in oral cancer development and progression.

Several decades of research have established that the protein kinase B (Akt)/mammalian target of rapamycin (mTOR) pathway is highly upregulated in oral cancer and leads to its development. The aforementioned risk factors for oral cancer such as tobacco, alcohol, and HPV were also found to induce activation of the Akt/mTOR pathway [11-13]. This pathway is a network of many proteins that interact and induce different cellular processes such as cancer cell survival, proliferation, invasion, angiogenesis, and tumor metastasis. Akt kinase is the key protein of this pathway and its activation is responsible for inducing tumorigenesis by affecting different hallmarks of cancer [14-26].

Multiple lines of evidence suggest that Akt isoforms are involved in the development of different cancers such as ovarian, colorectal, pancreatic, breast, and lung cancer [27-31]. However, it is well-known that Akt kinase exists in three different isoforms as Akt1, Akt2, and Akt3, and these display distinct functions in various cancers [32]. Additionally, the precise role of Akt isoforms in the development of oral cancer has not been studied thoroughly. Therefore, the present study intended to evaluate the role of different Akt isoforms in the pathogenesis of oral cancer. Moreover, an attempt was made to analyze their association with tobacco, the main risk factor for oral cancer. Deciphering the molecular network of Akt isoforms in the development of OSCC can provide a specific target against which appropriate therapeutic modalities can be developed for effective prevention and treatment of this disease.

\section{Materials and Methods}

\subsection{Tissue Microarray}

The Tissue microarray (TMA) slides for the oral cavity disease spectrum (oral cavity cancer progression) (OR802) were purchased from US Biomax, Inc (Derwood, MD, USA) and used for immunohistochemical analysis to determine the differential expression of Akt isoforms in the various developmental stages of oral cancer. The TMA slides contain 80 tissue cores from 79 individuals belonging to different age groups and gender. The tissues were further categorized based on disease pathology (28 squamous cell carcinoma, four adenocarcinoma, eight mucoepidermoid carcinoma, two basal cell carcinoma, four metastatic carcinoma, eight adamantinoma, six hyperplasia, five adjacent to cancer tissues, five inflammatory, five cancer adjacent normal tissues, and five normal tissues), anatomical site of disease (tongue, cheek, gingiva, lip, and palate), tumor stages (21 stage I, 15 stage II, one stage III, and five stage IV), and grades (24 grade 1, seven grade 2 , and seven grade 3 tissues).

\subsection{Immunohistochemistry}

Immunohistochemical analysis was performed using Histostain-Plus immunohistochemistry (IHC) Kit, horseradish peroxidase (HRP), broad spectrum (Invitrogen, Carlsbad, CA, USA) and HistoMouse-MAX Kit, 3,3'-Diaminobenzidine (DAB), broad spectrum (Invitrogen) as per the manufacturer's protocol. Antigen retrieval was performed by heating the tissue slides at $60{ }^{\circ} \mathrm{C}$ for $30 \mathrm{~min}$ in $0.01 \mathrm{M}$ citrate buffer ( $\mathrm{pH}$ 6.0). Rabbit monoclonal antibodies for Akt1 and Akt3 (Cell Signaling Technology, Danvers, MA, USA), and rabbit polyclonal antibody to Akt2 (Abcam, Cambridge, UK) were used for IHC. Finally, D-P-X. mountant (available in the kit) was used to mount the slides, 
and the tissue images were captured using a Nikon Eclipse T100 (Nikon, Shingawa, Tokyo, Japan) microscope and Nikon digital camera (Nikon).

\subsection{Immunohistochemistry-Scoring}

The staining intensity and percentage of positively stained cells were considered for the scoring of the expression of proteins. Each tissue specimen was assigned a score as per the intensity of the nuclear or cytoplasmic staining (no staining $=0$; weak staining $=1$; moderate staining $=2$; intense staining $=3$ ) and the frequency of stained cells (less than $10 \%=0 ; 10-25 \%=1 ; 26-50 \%=2 ; 51-75 \%=3$; $76-100 \%=4)$. The final expression score was calculated as the product of staining intensity and extent of positivity, with a minimum score of 0 and a maximum score of 12 [33-37].

\subsection{The Cancer Genome Atlas Dataset Analysis}

Information about the genetic alteration of Akt isoforms observed in head and neck carcinoma patient samples was obtained from the open data portal of The Cancer Genome Atlas (TCGA) and cbioportal platforms (http://www.cbioportal.org) [38,39]. Prognosis of patients associated with these alterations was evaluated in terms of overall survival (OS) and disease-free survival (DFS) by acquiring the Kaplan-Meier survival curve from the portal.

\subsection{Cell Culture}

The human oral cancer cell line SAS was acquired from the Rajiv Gandhi Centre for Biotechnology (RGCB), Trivandrum, India. The KB cells were obtained from the national animal cell repository National Centre for Cell Science (NCCS), Pune, India. The cells were cultured in Dulbecco's Modified Eagle Medium (DMEM) supplemented with 10\% v/v fetal bovine serum and 1\% v/v PenStrep and maintained at $37^{\circ} \mathrm{C}$ in a $\mathrm{CO}_{2}$ regulated incubator.

\subsection{Preparation of Tobacco Extract}

The dried leaves of tobacco were procured from the local market and ground into fine powder. $4 \mathrm{~g}$ of powder was dissolved in $100 \mathrm{~mL}$ of distilled water and stirred on an orbital shaker for $24 \mathrm{~h}$, subsequently filtered, and lyophilized. From the lyophilized powder, $50 \mathrm{mg} / \mathrm{mL}$ of stock solution was prepared and stored at $-20{ }^{\circ} \mathrm{C}$ for further use.

\subsection{MTT Assay}

The effect of tobacco and its components on the viability of SAS cells was estimated by 3-(4,5-dimethylthiazol-2-yl)-2,5 diphenyl tetrazolium bromide (MTT) reduction assay. Briefly, SAS cells were seeded in 96-well plates at a density of 4000 cells $/ 100 \mu \mathrm{L}$ per well and treated with different concentrations of tobacco extract (TE) $(0,25,50,100,250$, and $500 \mathrm{ng} / \mathrm{mL})$, benzo(a)pyrene (BAP) $(0$, $50,75,100,250$, and $500 \mathrm{ng} / \mathrm{mL})$, and nicotine $(0,0.05,0.1,0.25 .0 .5$, and $1 \mu \mathrm{M})$ for $24 \mathrm{~h}$. Following the 0 and $24 \mathrm{~h}$ treatment period, $10 \mu \mathrm{L}$ of $5 \mathrm{mg} / \mathrm{mL}$ MTT solution was added and incubated for $2 \mathrm{~h}$. Then the formazan crystals were dissolved in $100 \mu \mathrm{L}$ of dimethylsulfoxide (DMSO) and absorbance was measured at $570 \mathrm{~nm}$ with the help of a microplate reader (TECAN Infinite 200 PRO multimode reader, Meilen, Zurich, Switzerland). The \% cell viability was calculated after normalizing with the $0 \mathrm{~h}$ absorbance and considering the absorbance of the untreated control as 100\%.

\subsection{Reverse Transcriptase-Polymerase Chain Reaction}

SAS cells were treated with different concentrations of TE, BAP, and nicotine for $24 \mathrm{~h}$ and the total RNA was isolated using TRI reagent ${ }^{\circledR}$ (Sigma, St. Louis, MO, USA), and cDNA was synthesized using High-Capacity cDNA Reverse Transcription Kit (Invitrogen). One $\mu \mathrm{g}$ of total RNA was used for cDNA preparation. Further, these cDNAs were used for PCR amplification with Akt1, 2, and 3 isoforms, and $\alpha$-tubulin primers (Table 1 ). 
Table 1. Primer sequences

\begin{tabular}{|c|c|c|}
\hline Gene & Primer Sequence & Amplification Length \\
\hline \multirow{2}{*}{$A k t 1$} & 5'-CAC CAT GAG CGA CGT GGC TAT-3' & \multirow{2}{*}{$450 \mathrm{bp}$} \\
\hline & 5'-CCA GCA GCT TCA GGT ACT CA-3' & \\
\hline \multirow{2}{*}{$A k t 2$} & 5'-TTG CCA AGG ATG AAG TCG CT-3' & \multirow{2}{*}{$934 \mathrm{bp}$} \\
\hline & 5'-AAC CAC CCA GCG GTG ATG G-3' & \\
\hline \multirow{2}{*}{ Akt3 } & 5'-ATA ATC AGA TGT CTC CAG TG-3' & \multirow{2}{*}{$604 \mathrm{bp}$} \\
\hline & $5^{\prime}$-CTT GAG ATC ACG GTA CAC A-3' & \\
\hline \multirow[t]{2}{*}{$\alpha$-tubulin } & $5^{\prime}$-TAT CGA GCG CCC AAC CTA CAC T-3' & \multirow[t]{2}{*}{$683 \mathrm{bp}$} \\
\hline & 5'-ССТ САС ССТ СТС СТТ CAA CAG AAT C-3' & \\
\hline \multirow[t]{2}{*}{$\beta$-actin } & 5' - CTG GGA CGA CAT GGA GAA AA -3' & \multirow[t]{2}{*}{$564 \mathrm{bp}$} \\
\hline & 5' - AAG GAA GGC TGG AAG AGT GC -3' & \\
\hline
\end{tabular}

\subsection{Akt1/2 Gene Silencing}

In order to examine the isoform-specific roles of Akt isoforms, the genes were silenced by transfection with specific small interfering RNA (siRNAs). The siRNA sequences were custom synthesized by GeneX India Bioscience Pvt. Ltd (Chennai, India). The SAS cells were transfected by siRNAs using Lipofectamine RNAiMAX reagent (Invitrogen) using the manufacturer's protocol. After $36 \mathrm{~h}$, cells were harvested, whole cell lysate was prepared and used for further analysis. The scrambled sequence was used as siRNA control.

\subsection{Cell Cycle Analysis}

The effect of Akt1/2 knockdown on the cell cycle progression of SAS cells was determined by flow cytometry using PI/RNase solution (BD Biosciences, Fraklin Lakes, NJ, USA). SAS cells were transfected with siRNAs specific for Akt1 and Akt2 and scrambled siRNA. The transfected cells were harvested by trypsinization and fixed with $75 \%$ ice-cold ethanol overnight at $-20{ }^{\circ} \mathrm{C}$. Following the ethanol fixation, the cells were washed with $1 \times$ PBS and stained with PI/RNase solution. After 15 min of incubation with PI/RNase, the samples were analyzed using a flow cytometer (BD Biosciences FACSCalibur). FCS express software was used for analyzing the results and for determining the percentages of cells in each phase of the cell cycle.

\subsection{Clonogenic Assay}

Akt1/2 silenced SAS cells were seeded in six well plates at a concentration of 1000 cells/2 mL/well and treated with TE, BAP, or nicotine. The treated cells were incubated for 10 days to form colonies, with regular replenishing of culture medium. After 10 days, the colonies were fixed with chilled $6.0 \%$ glutaraldehyde, subsequently stained with crystal violet $(4 \% w / v)$ for 2 min and counted using ImageJ software (1.510 Version) [40]. The plating efficiency and survival fraction were calculated as follows: Plating efficiency $(\%)=($ Number of colonies counted/Number of cells plated $) \times 100$; Survival fraction $=$ (Plating efficiency of treated cells/Plating efficiency of control cells) [41].

\subsection{Migration Assay}

To determine the effect of Akt1/2 knockdown on the tobacco-induced migration of SAS cells, $7 \times 10^{5}$ cells $/ 2 \mathrm{~mL}$ were plated in 6-well cell culture plates and allowed to form a monolayer. Subsequently, the cells were serum starved for $8 \mathrm{~h}$. Following the serum starvation, a small scratch was made across the cell monolayer with the help of a $10 \mu \mathrm{L}$ sterile pipette tip and then treated with $50 \mathrm{ng} / \mathrm{mL}$ of TE and BAP, and $0.05 \mu \mathrm{M}$ of nicotine. Images of the scratch wound were captured at the same locations using a Nikon Eclipse T100 microscope and Nikon digital camera at 0, 12, and $24 \mathrm{~h}$ time intervals [42,43]. The captured images were then processed using ImageJ (1.510 Version) software to calculate the \% scratch wound area. 


\subsection{Flow Cytometric Assessment of Cell Viability}

A flow cytometry assisted propidium iodide (PI) exclusion assay was used to study the effect of knockdown of Akt1 and Akt2 on cell viability. Following siRNA transfection, the cells were harvested, washed with $1 \times$ PBS, stained with $10 \mu \mathrm{g} / \mathrm{mL}$ PI, and the percentage of dead cells was measured by flow cytometry (BD FACSCalibur, Franklin Lakes, NJ, USA).

\subsection{Western Blot Analysis}

Western blot analysis was performed to determine the expression of Akt isoforms and other important cellular proteins regulating the cancer hallmarks post knockdown. In short, total protein was extracted from the transfected SAS cells using whole cell lysis buffer containing $20 \mathrm{mM}$ HEPES, $2 \mathrm{mM}$ EDTA, $250 \mathrm{mM} \mathrm{NaCl}, 0.1 \%$ Triton- $X$, and protease inhibitors. The protein concentration was determined by Bradford assay, and bovine serum albumin (BSA) was used as the protein standard. Forty $\mu \mathrm{g}$ of protein lysate was loaded and resolved in a 12\% SDS-PAGE using the mini-PROTEIN 3-electrophoresis module assembly (Bio-Rad, Hercules, CA, USA). It was later transferred to a nitrocellulose blot membrane (Amersham Biosciences, Chiltern, UK) with the help of Trans-Blot ${ }^{\circledR}{ }^{\circledR}$ Turbo $^{\text {TM }}$ transfer system (Bio-Rad). The membrane was then blocked with 5\% non-fat dry milk in 1X TBST buffer for 2-3 h, the membrane was later washed thrice with 1X TBST buffer and incubated overnight with primary antibodies against Akt1, Akt2, and Akt3 (1:1000 dilution in 2\% BSA), GAPDH (CST 2118S, 1:2000 dilution in 2\% BSA), Bcl-2 (CST 15071, 1:1000 dilution in 2\% BSA), cyclin D1 (CST 2978, 1:2000 dilution in 2\% BSA), cyclooxygenase-2 (Cox-2, CST 12282, 1:2000 dilution in 2\% BSA), and survivin (CST 2808, 1:2000 dilution in $2 \%$ BSA) at $4{ }^{\circ} \mathrm{C}$. Subsequently, the membranes were washed with $1 \times$ TBST and incubated with horseradish peroxidase-conjugated anti-rabbit (ab97080, Abcam; 1:6000 dilution in 5\% milk) or anti-mouse secondary antibody (ab97040, Abcam; 1:6000 dilution in 5\% milk) for $3 \mathrm{~h}$. Further, the blots were washed again with 1X TBST and the protein bands were developed with Optiblot ECL Detection Kit (ab133406, Abcam). Image Lab ${ }^{\mathrm{TM}}$ Software (Bio-Rad) was used for densitometric analysis of the observed protein bands.

\subsection{Statistical Analysis}

All the results are presented as mean \pm standard error and the statistical analysis was performed using a Student's $t$-test and one-way analysis of variance (ANOVA). A $p$-value of $<0.05$ was accepted as statistically significant.

\section{Results}

In the present study we determined the role of different isoforms of Akt in oral cancer. First, we have analyzed the expression of Akt isoforms in oral cancer tissues by immunohistochemical analysis of TMA slides. Next, we evaluated the effect of genetic alterations of Akt isoforms on the prognosis of the disease in terms of OS and DFS from the TCGA dataset. Subsequently, we determined the effect of tobacco and its components such as BAP and nicotine on the expression of Akt isoforms in SAS and KB oral cancer cells. We also examined their effect on cell viability, clonogenicity, and migration of SAS cells. Later, in order to establish the role of Akt1 and 2 isoforms in the pathogenesis of oral cancer, we silenced these genes using siRNA and examined its effect on the growth, survival, proliferation, and migration of oral cancer cells and the involved molecular mediators.

\subsection{Overexpression of Akt1 and 2 Isoforms in Oral Cancer Tissues}

The IHC analysis of the Akt isoforms in the TMA slides showed overexpression of Akt 1 and 2 while there was no significant change in the expression of the Akt3 isoform in comparison to normal tissues (Figure 1A,B). On evaluating the expression in different tissue types such as normal, inflammation, hyperplasia, cancer adjacent tissues (CAT), and malignant tissues, it was found that the maximum expression of Akt1 and 2 was in malignant tumor types in comparison with normal tissues (Figure 1C). 
Moreover, the expression of Akt1 and 2 isoforms were found to be higher at the advanced stage of oral cancer (Figure 1D). Furthermore, an examination of the expression of Akt isoforms in different regions of the oral cavity showed increased expression of Akt1 and 2 in the lip, gingiva, lymph node, cheek, and tongue as compared to normal tissues. However, the palate region showed no significant increase in the expression of Akt1 and 2 isoforms. The expression of Akt1 was highest in tongue tissues, followed by gingiva and cheek, while cheek and gingiva showed maximum expression of Akt2, followed by the tongue (Figure 1E).
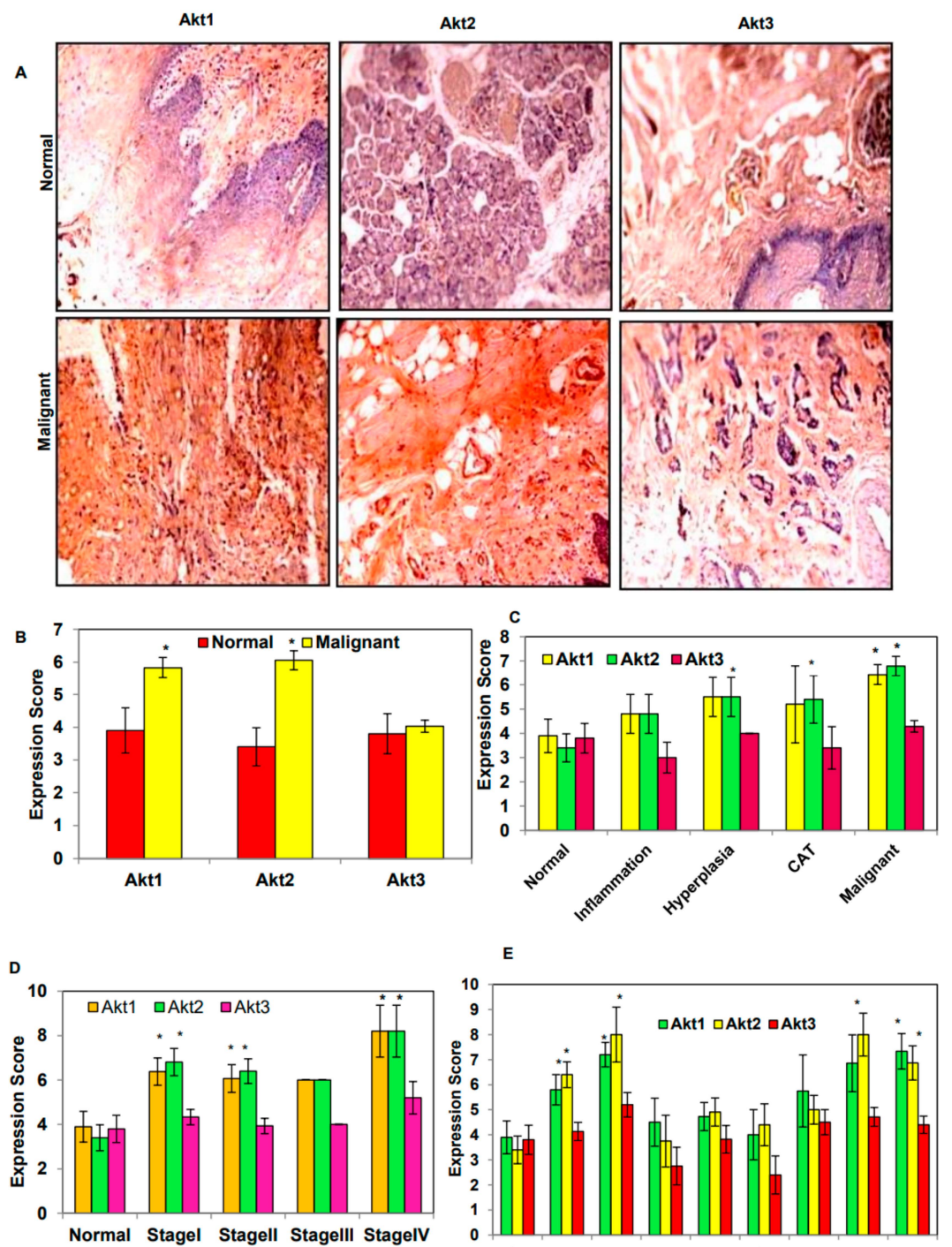

E

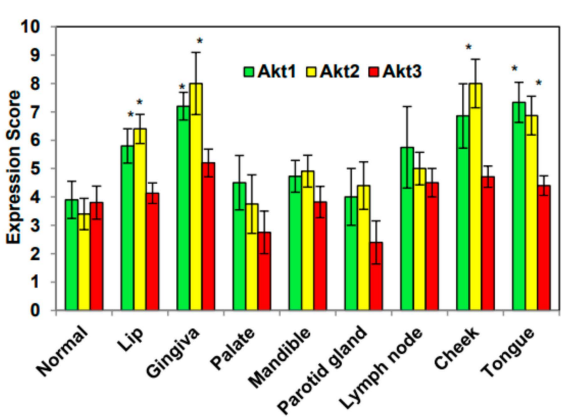

Figure 1. Expression of protein kinase B (Akt) isoforms in normal and malignant oral tissues through immunohistochemical analysis of the human oral cancer tissues. (A) Representative images showing the high expression of Akt1 and 2 isoforms in malignant tissues as compared to normal tissues at 10X magnification, (B) bar graph of the expression score for the normal $(n=10)$ and malignant $(n=70)$ tissues, (C) bar graph of the expression score for the normal tissues $(n=10)$, inflammation $(n=5)$, hyperplasia $(n=6)$, CAT $(n=5)$, (CAT: Cancer adjacent tissue), malignant tissues $(n=42),(D)$ bar graph of the expression score for the normal tissues $(n=10)$ and malignant tissues of stage I $(n=21)$, stage II $(n=15)$, stage III $(n=1)$, and stage IV $(n=5),(E)$ bar graph of the expression score for the normal $(n=10)$, lip $(n=15)$, gingiva $(n=5)$, palate $(n=4)$, mandible $(n=11)$, parotid gland $(n=5)$, lymph node $(n=4)$, cheek $(n=7)$, and tongue $(n=15)$. Data are expressed as the mean \pm standard error (SE). ${ }^{*}=p<0.05$ vs. Normal. 


\subsection{Genetic Alteration of Akt1 and 2 Isoforms Was Associated with Poor Overall Survival and} Disease-Free Survival

The mutational status of Akt isoforms in tissues of different cancer patients of head and neck squamous cell carcinoma (HNSCC) was studied as the data for OSCC could not be obtained. The different types of genetic alterations such as DNA amplifications, mutations, and deletions in 504 patients with HNSCC were obtained and analyzed from TCGA datasets. It was found that the maximum genetic alteration was present in Akt1 (2.8\%) followed by Akt3 (2.4\%) and Akt2 (2\%). The detailed assessment of the heatmap against the cases harboring the genetic alterations showed the increased mRNA transcript level of Akt1 and 2 isoforms, while for Akt 3 such observation was missing except in a few cases (Figure $2 \mathrm{~A}-\mathrm{C}$ ).

On consideration of the univariate analysis for survival data of 504 HNSCC patients from TCGA datasets, it was observed that the increasing abundance of genetic alterations of the Akt2 isoform was associated with worst overall survival (OS) and disease-free survival (DFS) in comparison to Akt1 and 3. The median OS and DFS of the patients with Akt2 genetic alteration were found to be reduced as 27.56 and 34.76 months, respectively, as compared to the cases with no alteration of the Akt2 gene (56.44 and 72.44 months). Similarly, patients harboring Akt1 gene alteration were also found to have a reduced OS of 45.93 months compared to patients with unaltered Akt1 (56.44 months), while the data for DFS could not be obtained (Figure 2D-I). The OS and DFS data for the Akt3 gene could not be acquired from the TCGA datasets.

\subsection{Tobacco and Its Components Increase the mRNA Levels of Akt1 and 2 Isoforms in SAS and KB Cells}

The effect of TE, BAP, and nicotine was assayed on the cell viability of SAS cells. It was found that the treatment with TE for $24 \mathrm{~h}$ induces proliferation of SAS cells. However, BAP and nicotine treatment could not induce such changes (Supplementary Materials Figure S1A-C). Later, the effect of tobacco and its components was analyzed on the expression of Akt isoforms. It was observed that the $24 \mathrm{~h}$ treatment of SAS and KB cells with TE, BAP, and nicotine increased the mRNA levels of Akt1 and 2 isoforms but not Akt3 (Figure 3). 

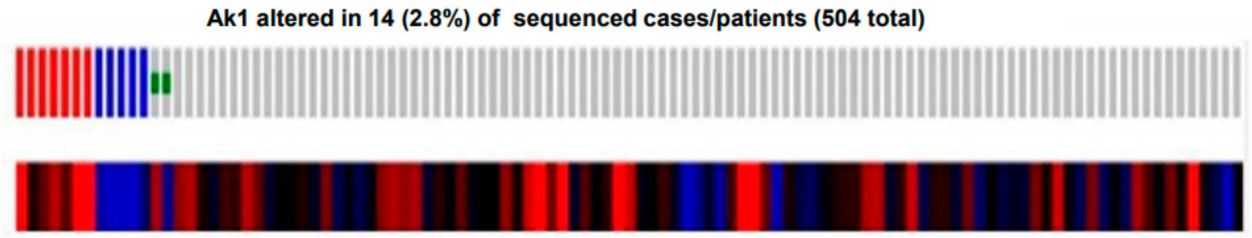
Ak2 altered in $10(2 \%)$ of sequenced cases/patients (504 total) \|\|$\|$ 年
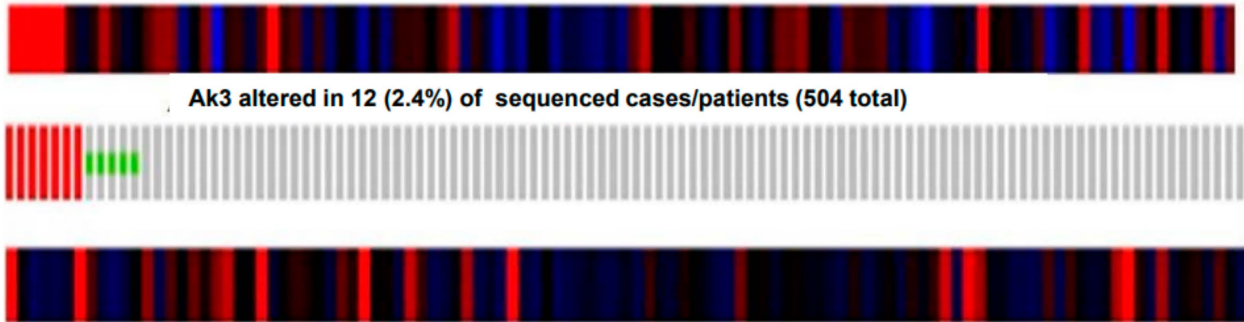

No Alteration Amplification

- Missense Mutation (unknown significance)

Deep Deletion

Iruncating Mutation (unknown significance)

D

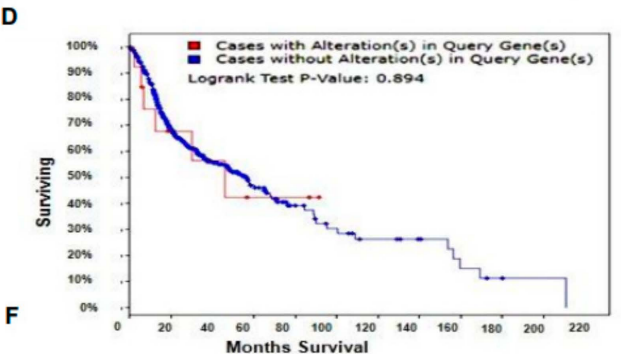

E
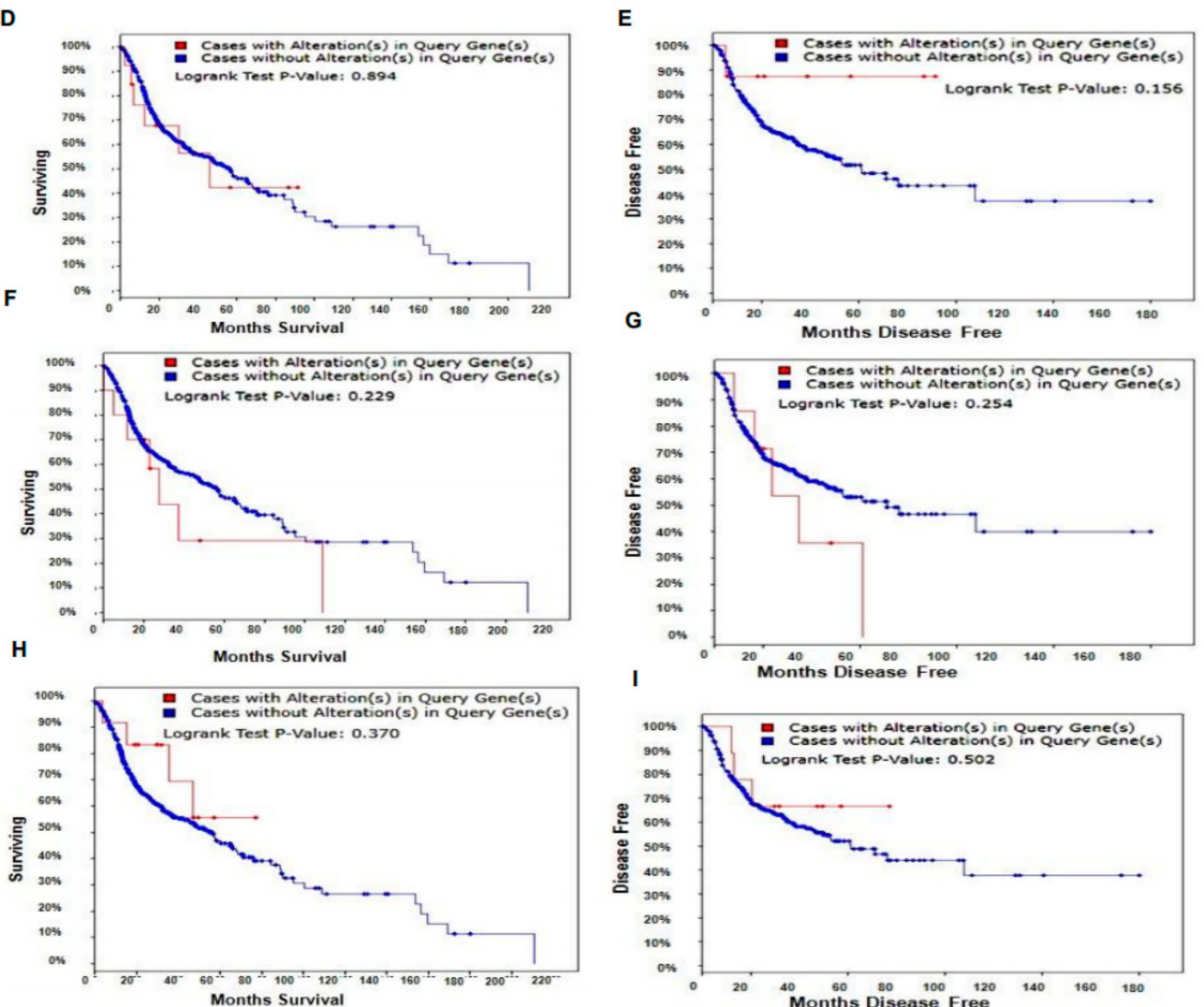

Figure 2. Genetic alterations of Akt isoforms present in 504 patients of head and neck squamous cell carcinoma (HNSCC) samples obtained from The Cancer Genome Atlas (TCGA) data portal. (A) Genetic alterations present in Akt1 (2.8\%), (B) Akt2 (2\%), (C) Akt3 (2.4\%) along with the heatmap showing their implications on the level of mRNA transcript. The Kaplan-Meier curves in the reference population showing the mutation alterations of $(\mathbf{D}, \mathbf{E}), \mathrm{Akt} 1 ;(\mathbf{F}, \mathbf{G}), \mathrm{Akt} 2$; and $(\mathbf{H}, \mathbf{I}), \mathrm{Akt} 3$ isoforms in correlation with overall survival (OS) and disease-free survival (DFS). The worst overall survival was observed in alterations related to Akt2 followed by Akt1. Data could not be obtained for the Akt3 isoform. 

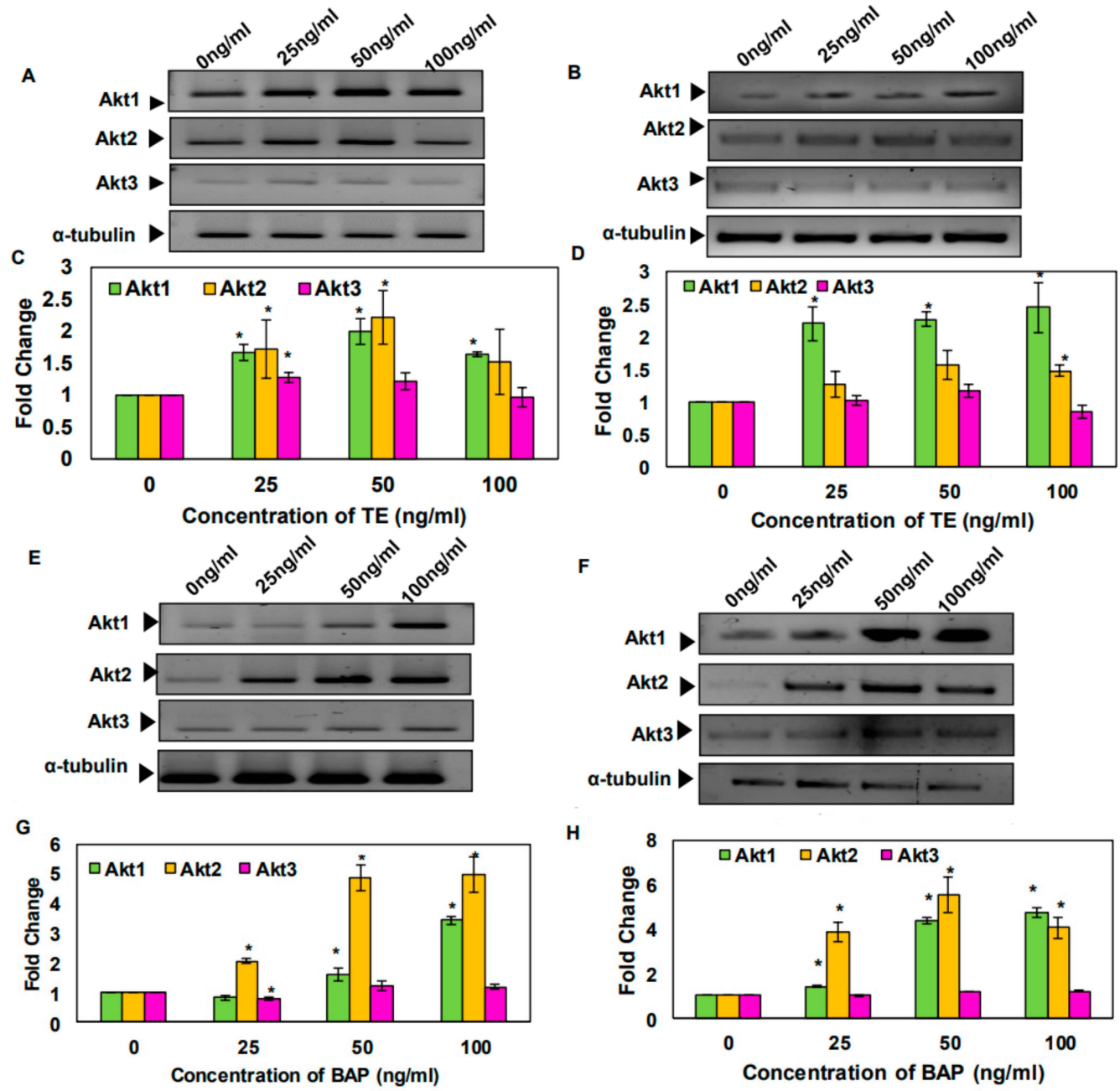

$H$
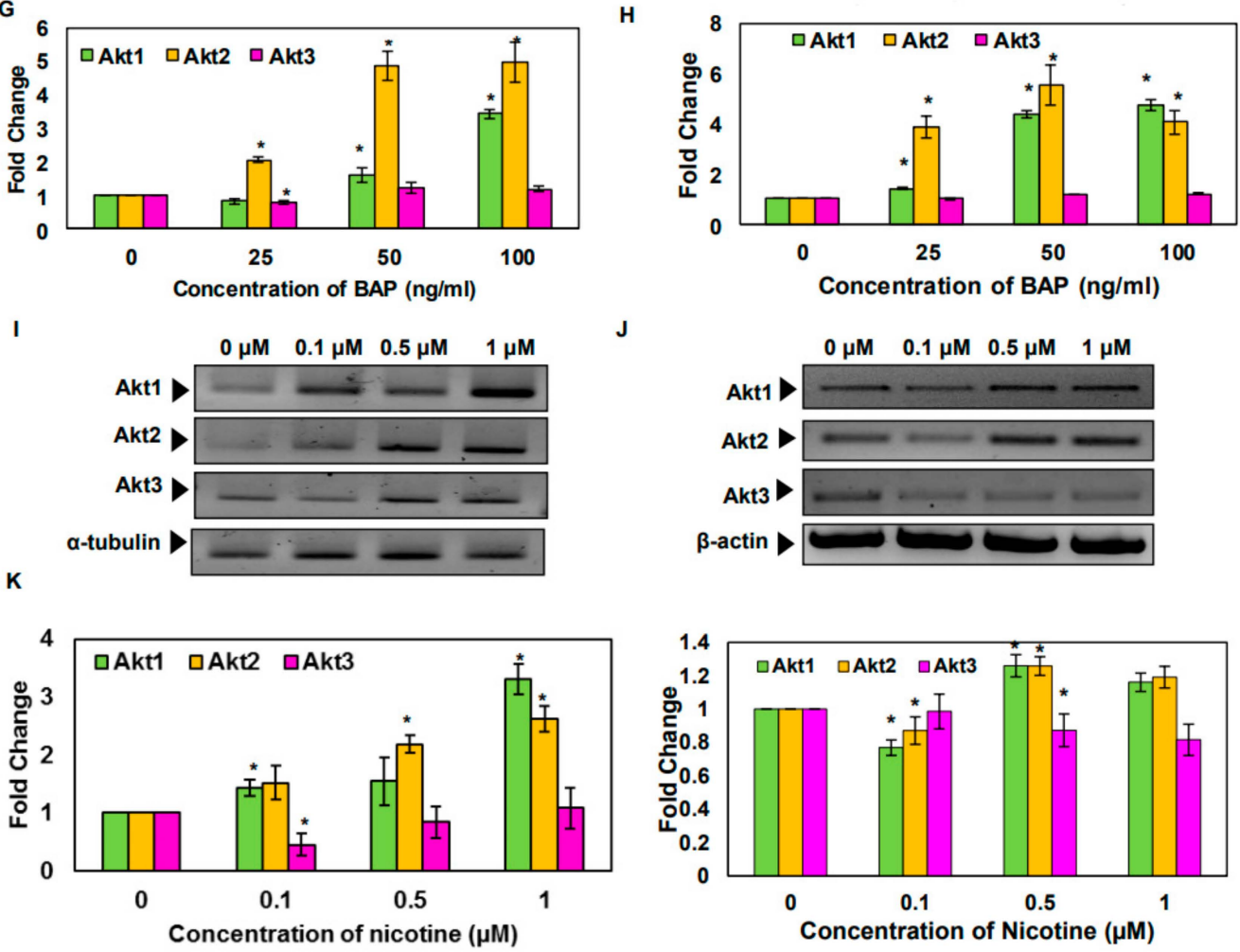

Figure 3. The tobacco extract (TE), benzo(a)pyrene (BAP), and nicotine induces the expression of Akt1 and 2 isoforms. (A,E,I) Reverse transcriptase-polymerase chain reaction (RT-PCR) analyses of the expression of Akt isoforms following treatment with TE, BAP, and nicotine in SAS cells. (B,F,J) RT-PCR analyses of the expression of Akt isoforms following treatment with TE, BAP, and nicotine in KB cells. $(\mathbf{C}, \mathbf{G}, \mathbf{K})$ Bar graph of mRNA expression of Akt isoforms in TE, BAP, and nicotine-treated SAS cells over untreated control in SAS cells. (D,H,L) Bar graph of mRNA expression of Akt isoforms in TE, BAP, and nicotine-treated SAS cells over untreated control in KB cells. Fold change in the expression was analyzed using Image Lab software. Data are means \pm SE. ${ }^{*}=p<0.05$. 


\subsection{Silencing of Akt1 and 2 Isoforms Led to Cell Cycle Arrest in G2/M Phase}

In order to understand the role of Akt1 and 2 in oral cancer, the specific genes were silenced using specific siRNAs. Silencing of Akt1 and 2 was observed to be isoform-specific and it reduced the expression of the respective genes by 80-90\% (Figure 4A-D). Moreover, silencing of Akt1 and 2 isoforms was observed to cause cell cycle arrest at the G2/M phase in SAS cells (Figure 4E-H).

A

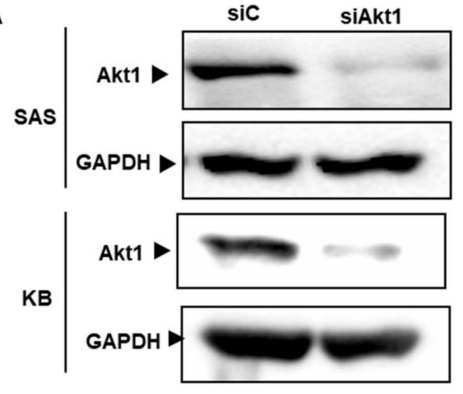

c
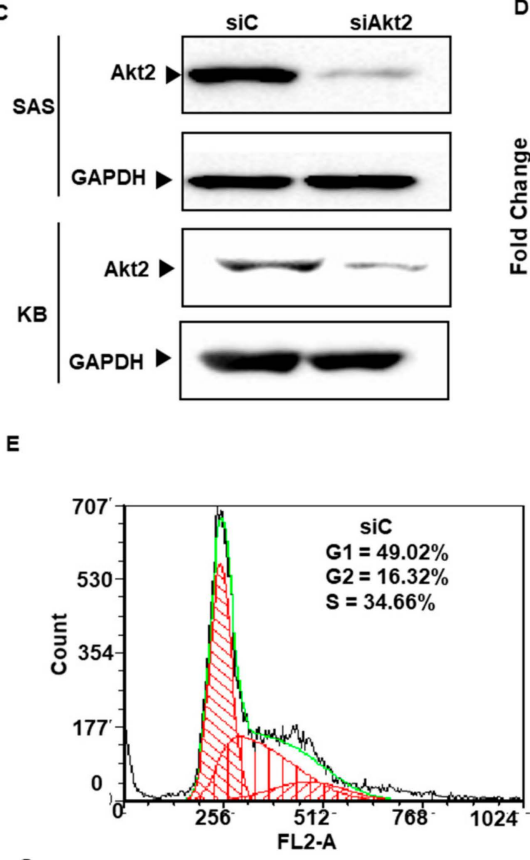

G

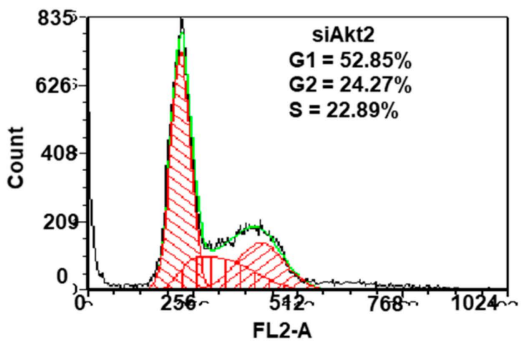

B

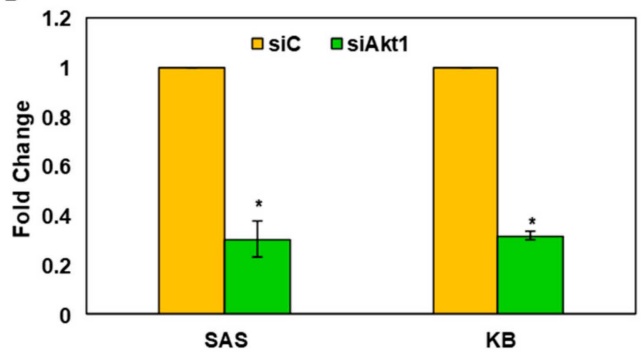

D

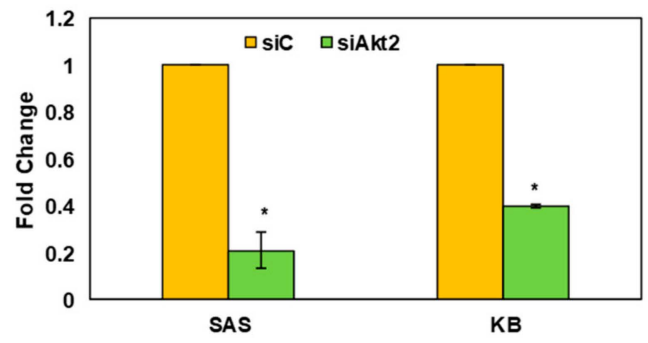

F
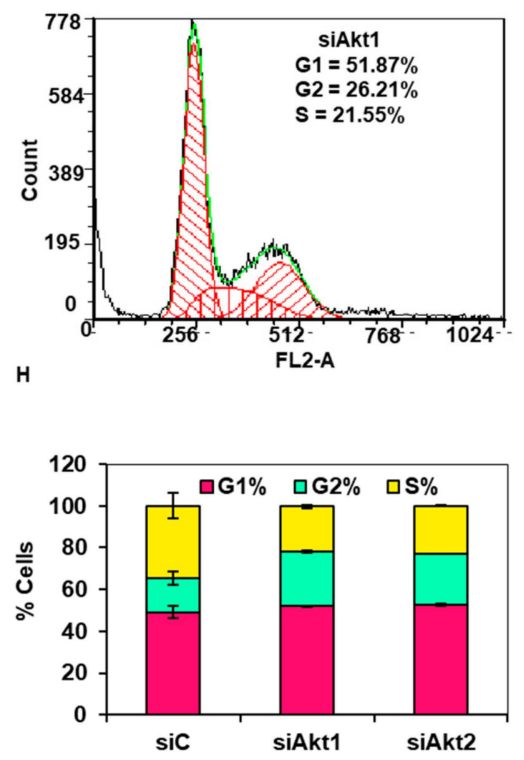

Figure 4. Knockdown of Akt1 and Akt2 in SAS cells and KB cells through siRNAs, and the effect on cell cycle arrest of SAS cells. (A,C) Representative image of the specific gene silencing of Akt1 and Akt2 by siRNA (siAkt1 and siAkt2) as analyzed by western blot assay. (B,D) Fold change in the expression of proteins on Akt1 and Akt 2 knockdown. Representative image of the cell cycle distribution as determined by DNA flow cytometric analysis in SAS cells (E) siC-treated cells, (F) siAkt1-treated cells, (G) siAkt2-treated cells. (H) Bar graph showing the \% of cells in G1, G2, and S phase. Fold change in the expression was analyzed using Image Lab software. Data are mean \pm SE. ${ }^{*}=p<0.05$. 


\subsection{Silencing of Akt1 and Akt2 Isoforms Decreases the Tobacco-Induced Clonogenicity of SAS Cells}

The effect of tobacco and its components on the clonogenic potential of SAS cells was evaluated pre and post Akt1/2 knockdown. It was observed that the treatment with tobacco carcinogens increased the colony forming potential of SAS cells up to certain concentrations. For instance, TE up to a concentration of $250 \mathrm{ng} / \mathrm{mL}$ was found to increase the colony forming efficiency up to 1.6-fold (Supplementary Materials Figure S2A) and this effect was found to be reduced upon silencing Akt1 and 2 genes (Figure 5A,B).

A

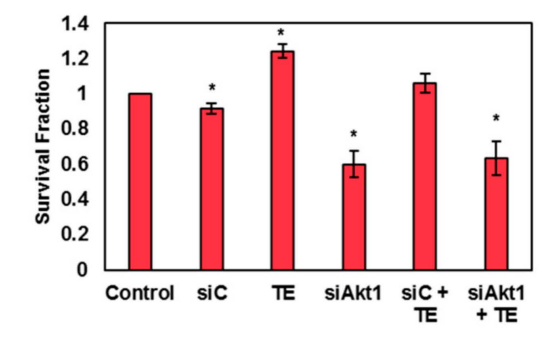

C

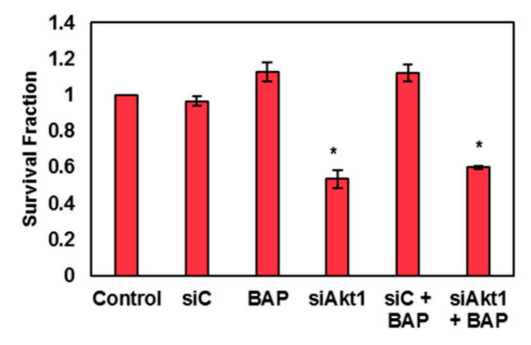

E

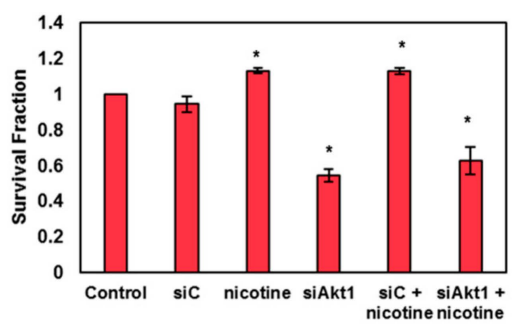

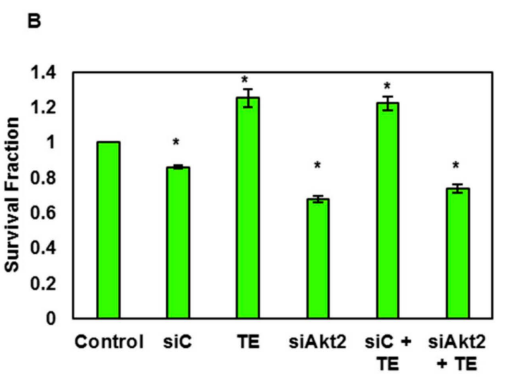

D

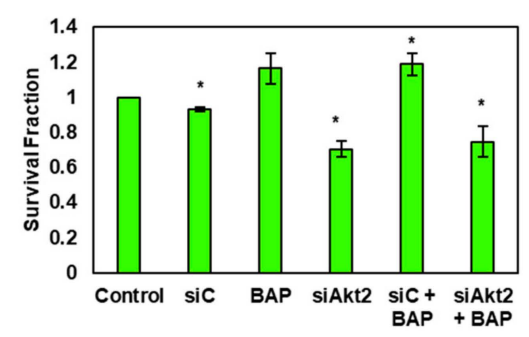

$\mathbf{F}$

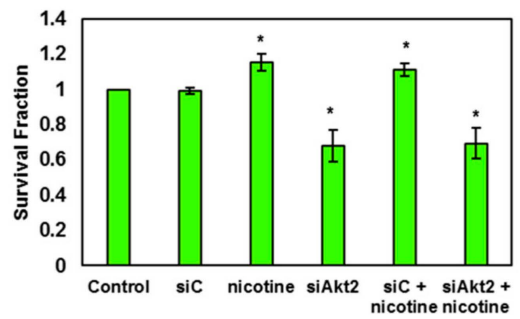

Figure 5. Clonogenic assay showing the survival efficiencies of SAS cells after knockdown of Akt1 and 2 isoforms following treatment with TE, BAP, and nicotine. Bar graph of clonogenic assay revealing the survival efficiencies of SAS cells after silencing of Akt1 and 2 isoforms following treatment with TE (A,B), BAP (C,D), and nicotine (E,F), (siC; Scramble control, siAkt1; siRNA for Akt1, siAkt2; siRNA for Akt2, TE; $50 \mathrm{ng} / \mathrm{mL}$ TE, $50 \mathrm{ng} / \mathrm{mL}$ BAP, $0.05 \mu \mathrm{M}$ nicotine). Data are mean $\pm \mathrm{SE} .{ }^{*}=p<0.05$.

Similarly, the BAP treated SAS cells were found to have 1.7 times increased survival fraction at a concentration of $250 \mathrm{ng} / \mathrm{mL}$ (Supplementary Materials Figure S2B), and Akt1/2 isoform silencing caused a reduction in BAP-induced clonogenicity of the SAS cells (Figure 5C-D). Finally, the clonogenic potential of nicotine-treated SAS cells was also found to be increased 1.3 times up to $0.5 \mu \mathrm{M}$ concentration (Supplementary Materials Figure S2C), and it was also decreased after silencing the Akt1 and 2 isoform expression (Figure 5E-F).

\subsection{Silencing of Akt1 and Akt2 Isoforms Decreases the Tobacco-Induced Migration of SAS Cells}

The wound healing assay was performed to analyze the effect of silencing of the Akt1 and 2 isoforms on TE, BAP, and nicotine-induced migration of oral cancer cells. It was found that TE treatment increased the migration potential and consequently decreased the wound area over the $24 \mathrm{~h}$ 
interval time. Likewise, the treatment with BAP and nicotine also led to an increase in the migration potential, causing a decrease in the wound area, although the healing capacity was less when compared to TE treated cells (Supplementary Materials Figure S3A-C). Subsequently, analysis of the effect of Akt1/2 gene silencing was studied on tobacco-induced migration of SAS cells. It was found that the knockdown of Akt2 gene led to a reduction in the migration potential of oral cancer cells. However, silencing of Akt1 failed to decrease the migration potential of both tobacco-treated and untreated SAS cells (Figure 6A-C).

A

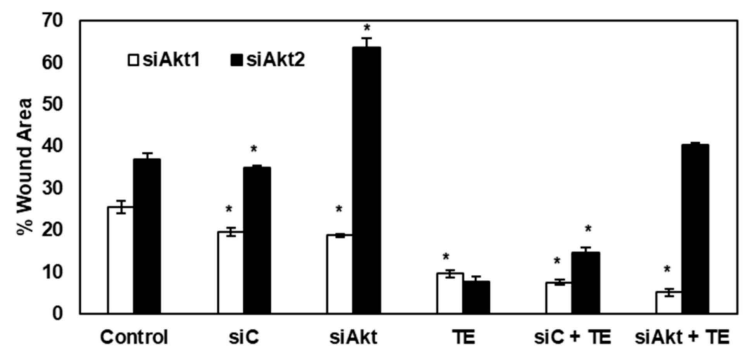

B

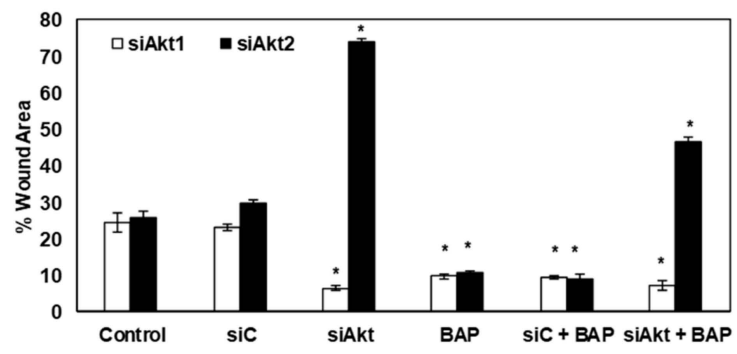

C

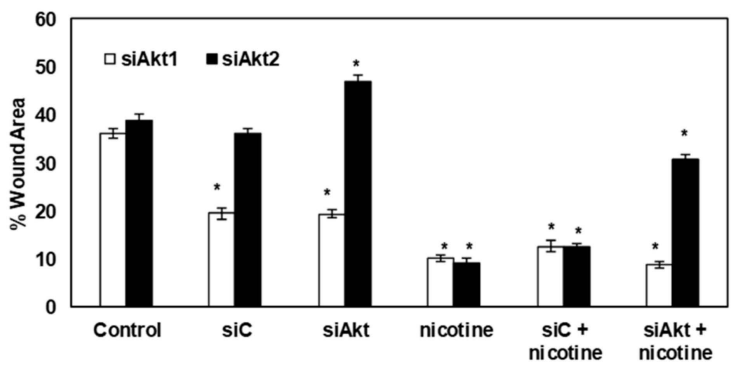

Figure 6. Effect of TE, BAP, and nicotine after silencing of Akt1 and 2 isoform on SAS cell migration. (A-C) The \% of cell-covered area (wound area) shown in the bar diagram was estimated using the Image J software (siC; Scramble control, siAkt1; siRNA for Akt1, siAkt2; siRNA for Akt2, TE; $50 \mathrm{ng} / \mathrm{mL}$, $\mathrm{BAP} ; 50 \mathrm{ng} / \mathrm{mL}$, nicotine; $0.05 \mu \mathrm{M})$. Data are mean \pm SE. ${ }^{*}=p<0.05$.

3.7. Silencing of Akt1 and 2 Isoforms Decreased Cell Survival and Expression of Proteins Associated with Cell Survival and Proliferation

The PI exclusion assay by flow cytometry revealed an increased percentage of cell death (approximately 26\%) in Akt1 and 2 knockdown cells compared to the controls (Figure 7A-D). Further, the western blot analysis of the Akt1 and 2 knockdown cells demonstrated a significant decrease in the expression of cyclin D1, Bcl-2, and survivin proteins only in Akt2 knockdown cells but no significant change was observed in Akt1 knockdown cells. However, both Akt1 and Akt2 knockdown was associated with decreased levels of Cox-2 protein expression (Figure 7E-H). 
A

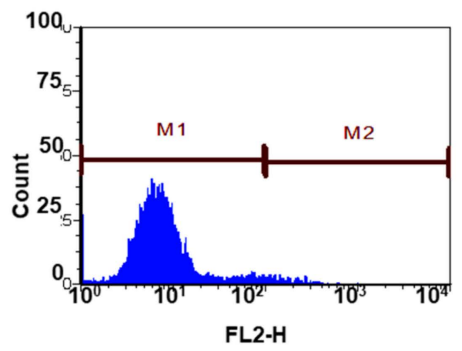

c

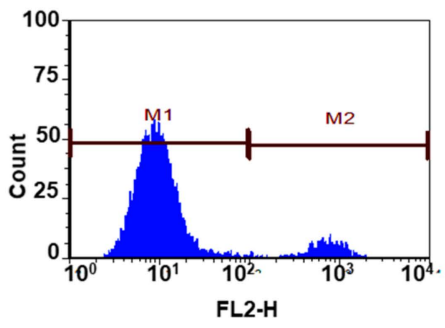

E
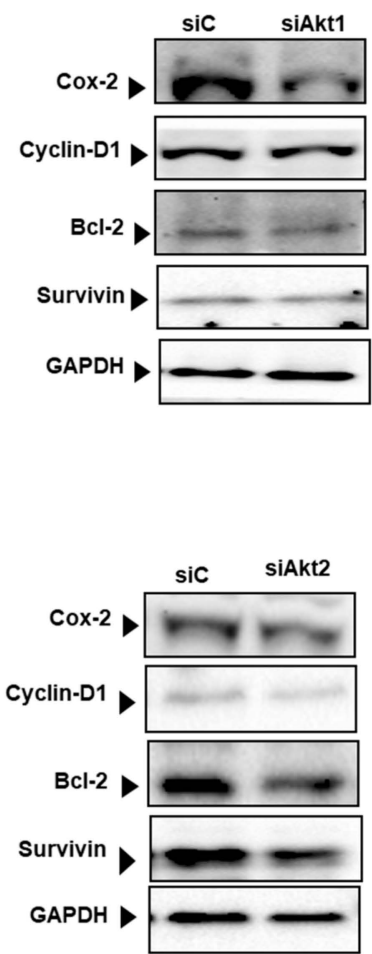

B
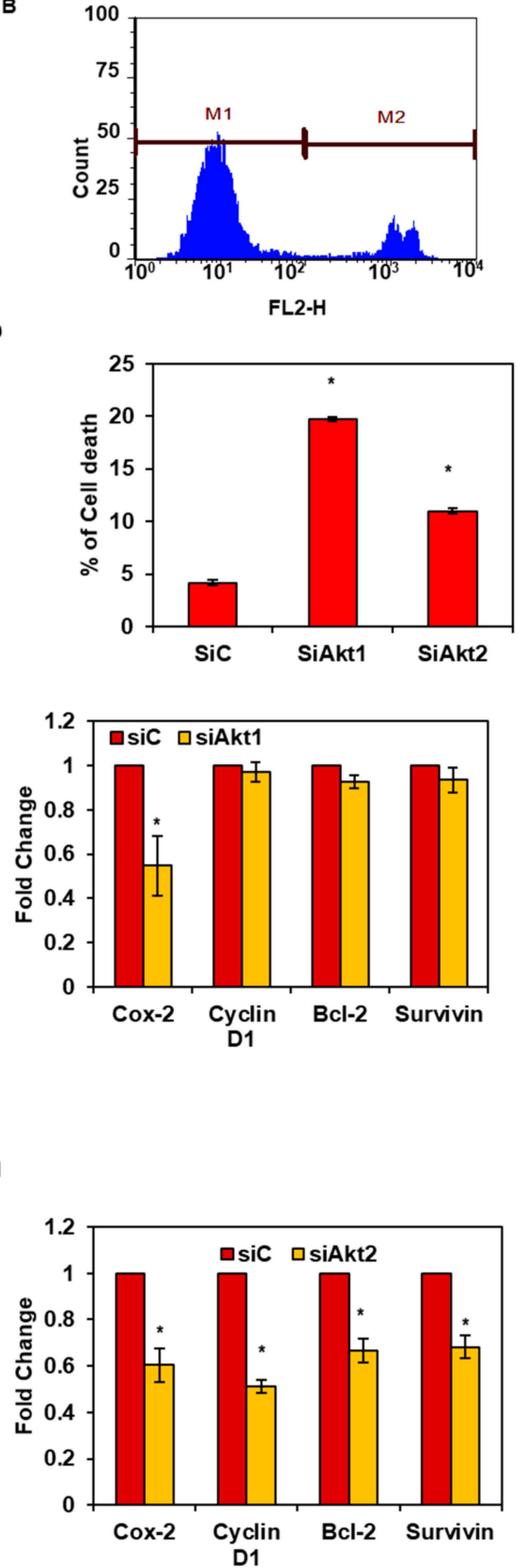

Figure 7. Knockdown of Akt1 and Akt2 in SAS cells. Representative image showing the cell death percentage on treatment with (A) siC, (B) siAkt1, and (C) siAkt2 as analyzed by PI uptake method, (D) bar graph showing the percentage of cell death, $(\mathrm{E}, \mathrm{G})$ representative image of the effect of gene silencing of Akt1 and Akt2 by siRNA (siAkt2) in SAS cells as analyzed by western blot assay, (F) and (H); bar graph showing the fold change of Cox-2, Cyclin D1, Bcl-2, and survivin protein expression in Akt1 and 2-knockdown SAS cells over scramble control. Fold change in the expression was analyzed using Image Lab software. Data are means $\pm \mathrm{SE}^{*}=p<0.05$.

\section{Discussion}

This is the first study that shows the role of different isoforms of Akt in oral cancer. Analysis of the differential expression of Akt isoforms in oral cancer tissues showed overexpression of Akt1 and 2 isoforms. Additionally, the expression of Akt1 and 2 isoforms varied with the different stages of cancer and it gradually increased with advanced stages of oral cancer. A previous report by Iamaroon and Krisanaprakornkit has also shown the overexpression of Akt1 and 2 in OSCC [44]. Moreover, 
the overexpression of Akt1 and 2 isoforms have been reported in many other cancers such as breast, liver, lung, glioma, and neuroblastoma [32]. Differential expression of Akt isoforms was also observed in several tumor tissue types, and previous studies have suggested the important role of Akt isoforms in inflammatory conditions, especially in vascular diseases $[45,46]$. However, no such study of Akt isoform-specific involvement in other tissue types has been reported. In line with our observations, the expression of Akt1 and 2 were found to be different in early and late stages of breast cancer [47].

Our study has shown the overexpression of Akt1 and 2 isoforms in different regions of the oral cavity such as the tongue, cheek, and gingiva. A couple of studies have shown the activation of Akt in tongue cancer is associated with adverse outcomes [48,49]. Thus, it might be possible that out of all three isoforms, only Akt1 and 2 play a key role in tongue cancer development. On exploring the TCGA dataset, it was observed that all three Akt kinase isoforms have a considerable percentage of genetic alterations in HNSCC, but in our study, the IHC analysis of oral cancer tissues showed high expression of Akt1 and 2 isoforms but not Akt 3 compared to the normal tissues. The HNSCC includes different types of cancer including OSCC. OSCC is more confined to the oral cavity region, which is different from the other section of the head and neck region such as oropharynx and larynx. The other regions of the head and neck are different from the oral cavity region both physiologically and histologically and this difference might be responsible for a discrepancy in the association of Akt isoforms. The disparity in the association of Akt isoforms is not only limited to HNSCC and OSCC but prevalent in other cancers as well. Regardless of the discrepancy in the association of the Akt isoforms in HNSCC and OSCC, only the genetic alteration associated with Akt1 and 2 isoforms were associated with poor OS and genetic alteration of Akt2 isoform was linked with poor DFS of HNSCC patients. Consistent with our observations, previous reports have also implied the profound significance of Akt1 and 2 gene expression in the prognosis of different cancers such as esophageal squamous cell carcinoma and non-small cell lung carcinoma [32,50-54]. Therefore, it becomes evident that both Akt1 and 2 might play a significant role in clinical outcomes of oral cancer patients. Therefore, a detailed mechanistic interpretation can help in deciphering the distinct role of Akt isoforms in oral cancer development, thereby allowing effective therapeutics to be developed.

It is well recognized that tobacco is a prime risk factor for oral cancer, and our results have shown increased cell proliferation of oral cancer cells following treatment with tobacco and its components. In line with our results, previous studies have also suggested the increased proliferation of cancer cells on exposure to tobacco [55,56]. Moreover, many studies have suggested that treatment with the tobacco component BAP can increase the proliferation of normal cells and cancer cells such as ovarian, breast, lung, and gastric cancer cells [57-60]. Nicotine is an important component of tobacco and it has long been associated with several cancers such as cancers of lung, head and neck, gastric, pancreatic, gallbladder, liver, colon, breast, cervical, urinary bladder, and kidney [61].

Several studies have suggested that treatment with nicotine can increase the proliferation of immortalized oral keratinocytes and other cancer cells [62,63]. Moreover, a recent study has suggested the association of nicotine with the promotion of tongue squamous cell carcinoma (TSCC) progression [64]. In our study, we found that treatment of oral cancer cells with tobacco and its components such as BAP and nicotine increased the transcript level of Akt1 and 2 isoforms. Similar to our results, several other reports have also indicated the isoform-specific involvement of Akt kinase in tobacco-induced cancer. In one such study, the importance of Akt1 or 2 isoforms in the nicotine-derived nitrosamine ketone-induced lung tumor formation has been shown in vivo $[65,66]$. In the case of urothelial cell carcinoma, the tobacco treatment was found to upregulate the Akt1 and 2 isoforms along with other molecular mediators such as Harvey rat sarcoma viral oncogene homolog (HRAS) and Ras-related C3 botulinum toxin substrate 1 [67].

Our preliminary study indicated that Akt1 and 2 are primarily overexpressed in oral cancer tissues and also the TCGA dataset revealed the genetic alteration associated with Akt1 and 2 isoforms increased the transcript level but not the Akt3 isoform. Furthermore, the study suggested that Akt1 and 2 isoforms were majorly affected upon treatment with tobacco and its components, whereas no 
such effect was observed in the case of Akt3 isoform. Therefore, we focused only on Akt1 and 2 isoforms for our further analysis. In our study, the silencing of Akt1 and 2 isoforms caused cell cycle arrest in the G2/M phase, and prior studies have also suggested the involvement of Akt in G2/M cell cycle arrest $[68,69]$. Furthermore, it is known that arrest in the G2/M phase leads to apoptosis of cancer cells [70]. We further found that treatment with tobacco and its components such as BAP and nicotine increased the clonogenic potential of oral cancer cells, which was reduced by silencing Akt1 and 2 isoforms. Previous studies have also indicated the role of benzo(a)pyrene dihydrodiol epoxide, a byproduct of BAP, in the regulation of cell survival through microRNA-29a [71]. In line with our observations, treatment with nicotine was found to increase the clonogenic potential of various cancer cells [72,73]. In addition, silencing of Akt1 and 2 decreased the clonogenic efficiency of untreated and tobacco-treated cells. Similarly, other studies have also indicated the important role of Akt isoforms in clonogenesis of different cancer cells such as glioma, glioblastoma, lung, neuroendocrine, and chronic myeloid leukemia $[69,74-78]$. From these studies, it appears that these isoforms play a discrete role in colony formation of different cancer cells. There are several reports available that have suggested that tobacco and its components can increase the migration potential of different cancer cells such as breast, colon, and lung [56,79-82]. Recently, a report from Zhang and group have suggested that treatment with BAP promotes the migration and invasion of lung cancer cells through up-regulating the expression of cytokine IL8 and chemokines C-C motif Ligand 2 (CCL2) and CCL3 [83]. The study suggested the differential effect of tobacco, nicotine, and BAP in cell proliferation, cell survival, and migration of cancer cells. This observation is quite obvious as crude tobacco extracts have different phytochemicals, which include nicotine and BAP and their combination can bring different outcomes. Moreover, the mechanism of nicotine and BAP in the process of carcinogenesis is divergent, therefore, their treatment would produce the differential effect with respect to different processes of cancer development [84]. In our study, the silencing of Akt2 reduced oral cancer cell migration, and a similar observation has been reported for breast cancer cells also [47]. In mesenchymal stem cells, it was also observed that pharmacological inactivation of Akt2 but not Akt1 significantly decreased cell migration and invasion [85]. However, in lung cancer, a partial reduction in scratch wound healing migration was observed in Akt2 knockdown cells while the prominent effect was observed in Akt1 knockdown cells [69].

In our analysis, we found that the silencing of Akt 1 and 2 isoforms caused an increase in the percentage of cell death in oral cancer cells. Likewise, previous studies have also suggested the importance of Akt1 and 2 in cell survival and indicated that these isoforms mediate the process of cell survival through different routes $[69,86,87]$. Similar to our results, in other cancers such as breast, lung, and colorectal cancers, the important role of Akt1 and 2 isoforms have been shown in the process of cell survival through induction of apoptosis $[47,69,88]$. Finally, we observed that silencing of Akt2 led to the decreased expression of proteins such as Cox-2, Cyclin D1, Bcl-2, and survivin, while silencing of Akt1 only led to a reduction in Cox-2 levels. Cox-2 and serine threonine kinase Akt signaling pathway possess a strong correlation [89]. For instance, in the case of endometrial cancer, Akt was found to regulate the expression of Cox-2 at both gene and protein level in phospho-Akt expressing cells [90]. Further, in epithelial ovarian cancer, overexpression of COX-2 was reported to be strongly associated with Akt activation, suggesting the correlation between Cox-2 and Akt [91].

Cox-2 is one of the two isoforms of the COX enzymes that catalyzes the conversion of arachidonate to Prostaglandin H2 (PGH2; a type of prostaglandin). Prostaglandins are known to play an important role in different physiological processes such as immune function regulation, reproductive biology, kidney function, and gastrointestinal integrity [92]. Different studies have indicated the higher expression of Cox-2 in pre-cancerous lesions and oral cancer tissues as compared to the normal tissues [93-97]. Tobacco and areca nut, which are the important risk factors associated with oral cancer, have been shown to induce the expression of Cox-2 and might contribute to the tumorigenesis process. Different chemical components such as hydroxychavicol, a component of areca quid (AQ), NNK and nicotine (active component of tobacco) induce the expression of Cox-2 in the oral cells 
and can contribute to the carcinogenesis process [93,98-100]. It was suggested that their expression is required for the onset of the carcinogenesis process. Furthermore, the different lines of evidence suggest that Cox-2 mediates the process of metastasis of cancer cells in OSCC and TSCC [101-107]. Moreover, their important role as a prognostic biomarker in predicting the outcome of oral cancer patients has been indicated [108-111]. Different functional polymorphisms of Cox-2 gene has been indicated to modify the risk status of oral cancer patients [112,113]. In a recent paper, the important role of Cox-2 in mediating inflammation in OSCC was discussed. It was also suggested that the blockage of this pathway can help in proliferation and progression of tumor cells and thus can potentially help cancer patients in improving their quality of life and survival rates [114]. Many previous studies have suggested the importance of Cox-2 in other cancers such as cancers of colorectal, breast, prostate, and blood. Moreover, in endometrial and lung cancer, Cox-2 was reported to be a downstream target of Akt and plays a significant role in the regulation of apoptosis of cancer cells [72,90,115,116]. In our study, we observed that the knockdown of both Akt1 and 2 isoforms led to the reduction of Cox-2 protein expression. In line with our observation, the previous study has shown the link between decreased Cox-2 expression with silencing of Akt1 and 2 isoforms. It was suggested that decreased Cox-2 expression was associated with reduced migration and invasion of lung cancer cells [117].

The protein Cyclin D1 encodes the regulatory subunit of the holoenzyme that regulates the phosphorylation and inactivation of retinoblastoma protein and thereby promotes the progression of cells through the G1/S phase of the cell cycle [118]. Many reports have suggested that the PI3K/Akt pathway is a strong activator of Cyclin D1, which is an important regulator of apoptosis. It is well known that GSK-3 is responsible for the degradation of Cyclin D1, which can be inactivated by Akt through phosphorylation [119]. In our study, we found that silencing of Akt2 led to the reduction of Cyclin D1 expression. In contrast to our result, Akt1 but not Akt2 was found to modulate the expression of Cyclin D1 in lung and breast cancer cells $[47,120]$. Akt is known to play a central role in the mediation of apoptosis through regulation of the Bcl-2 protein family members, which include Bcl-2, an anti-apoptotic protein [121,122]. The expression of survivin is also known to be regulated by the PI3K/Akt pathway in different cancers [123]. It might be possible that these proteins are being regulated by the Akt2 isoform. Based on our investigations, it can be suggested that the selective inhibition of Akt1 or Akt2 isoforms would be a better approach for the management of oral cancer. Overall, in our study, we found that the Akt1 and 2 isoforms play a differential role in different processes of OSCC and accordingly need to be dealt with on a case by case basis. However, the major limitation of our study is the lack of detailed mechanistic involvement of the Akt3 isoform in oral cancer, which can be evaluated in the near future to get an in-depth understanding of the disease.

\section{Conclusions}

The current study aimed at evaluating the expression and delineating the role of different Akt isoforms in the development of oral cancer. Our results suggest the overexpression of Akt1 and 2 with respect to migration and expression of Bcl-2, cyclin D1, and survivin proteins, which are important for cancer cell survival and proliferation. However, our study has not elucidated the detailed role of the Akt3 isoform, which might play an important role in HNSCC and hence should be studied in the near future. Therefore, general targeting of the total Akt kinases would not be effective in the prevention and treatment of oral cancer. Specific targeting of the Akt1 and 2 isoforms would result in a better prognosis for oral cancer patients. Moreover, our results also indicated a strong association of Akt1/2 isoforms with tobacco (one of the major risk factors of oral cancer) induced cancer cell viability and migration, which can be further studied to explore the other molecular mediators linked with Akt isoforms and tobacco mediated oral carcinogenesis, and to establish a signaling axis that regulates this process. In addition, future studies should also be concentrated on selective inhibition of Akt1 and 2 isoforms, with experimental validation for the development of effective therapy against oral cancer. 
Supplementary Materials: The following are available online at http://www.mdpi.com/2218-273X/9/7/253/s1, Figure S1: Effect of A; TE, B; BAP, and C; nicotine on the proliferation of SAS cells as analyzed by MTT assay (\% Proliferation values shown are the average of three independent experiments). Figure S2: Clonogenic assay showing the survival efficiencies of SAS cells after treatment with TE, BAP, and nicotine. A, B, and C; Bar graph of clonogenic assay revealing the survival efficiencies of TE, BAP, and nicotine-treated SAS cells. Data are means $\pm \mathrm{SE}^{*}=p<0.05$. Figure S3: The treatment of TE, BAP and nicotine increases the directional cell migration as observed by the scratch wound healing assay. A, B, and C; Bar graph showing the \% of cell-covered area (wound area) are shown in the bar diagram was estimated using the ImageJ software (1.510 Version). Data are means $\pm \mathrm{SE}$ $*=p<0.05$.

Author Contributions: Conceptualization, A.B.K.; Data curation, J.M. and N.K.R.; Formal analysis, H.L., N.S.K., A.K.S., M.N.B., G.N.A., I.L.; Methodology, N.K.R., J.M.; Project administration, N.K.R., J.M., G.P. and A.B.K.; Resources, A.B.K. and A.P.K.; Supervision, A.B.K.; Validation, G.P. and D.B.; Visualization, A.B.K. and A.P.K.; Writing—original draft, A.B.K. and A.P.K.; Writing—review \& editing, F.A., D.B. and G.P.

Funding: This project was supported by NCD/NER/4/2018-19 (dt. 22.06.2018) awarded to A.B.K. by Indian Council of Medical Research (ICMR), Government of India. N.S.K. thanks the Advanced Level State Biotech Hub, Mizoram University (BT/04/NE/ 2009 dt. 29.08.2014) sponsored by the Department of Biotechnology (DBT), Government of India for the Infrastructural support. The author N.K.R. acknowledges the UGC for providing the fellowship.

Conflicts of Interest: The authors declare no conflicts of interest.

\section{References}

1. Torre, L.A.; Bray, F.; Siegel, R.L.; Ferlay, J.; Lortet-Tieulent, J.; Jemal, A. Global cancer statistics, 2012. CA Cancer J. Clin. 2015, 65, 87-108. [CrossRef] [PubMed]

2. Silverman, S.; Gorsky, M. Epidemiologic and Demographic Update in Oral Cancer: California and National Data-1973 to 1985. J. Am. Dent. Assoc. 1990, 120, 495-499. [CrossRef] [PubMed]

3. Blot, W.J.; McLaughlin, J.K.; Winn, D.M.; Austin, D.F.; Greenberg, R.S.; Preston-Martin, S.; Bernstein, L.; Schoenberg, J.B.; Stemhagen, A.; Fraumeni, J.F. Smoking and drinking in relation to oral and pharyngeal cancer. Cancer Res. 1988, 48, 3282-3287. [PubMed]

4. De Stefani, E.; Victora, C.G.; Castelletto, R.; Castellsagué, X.; Muñoz, N.; Rolón, P.A.; Quintana, M.J. Independent and joint effects of tobacco smoking and alcohol drinking on the risk of esophageal cancer in men and women. Int. J. Cancer 1999, 82, 657-664.

5. Schlecht, N.F. Prognostic value of human papillomavirus in the survival of head and neck cancer patients: An overview of the evidence. Oncol. Rep. 2005, 14, 1239-1247. [CrossRef] [PubMed]

6. Fakhry, C.; Westra, W.H.; Li, S.; Cmelak, A.; Ridge, J.A.; Pinto, H.; Forastiere, A.; Gillison, M.L. Improved Survival of Patients with Human Papillomavirus-Positive Head and Neck Squamous Cell Carcinoma in a Prospective Clinical Trial. J. Natl. Cancer Inst. 2008, 100, 261-269. [CrossRef] [PubMed]

7. Manoharan, N.; Tyagi, B.B.; Raina, V. Cancer incidences in rural Delhi-2004-05. Asian Pac. J. Cancer Prev. 2010, 11, 73-77.

8. Bell, R.B.; Kademani, D.; Homer, L.; Dierks, E.J.; Potter, B.E. Tongue Cancer: Is There a Difference in Survival Compared With Other Subsites in the Oral Cavity? J. Oral Maxillofac. Surg. 2007, 65, 229-236. [CrossRef]

9. Massano, J.; Regateiro, F.S.; Januário, G.; Ferreira, A. Oral squamous cell carcinoma: Review of prognostic and predictive factors. Oral Surgery Oral Med. Oral Pathol. Oral Radiol. Endodontol. 2006, 102, 67-76. [CrossRef]

10. Mydlarz, W.K.; Hennessey, P.T.; Califano, J.A. Advances and Perspectives in the Molecular Diagnosis of Head and Neck Cancer. Expert Opin. Med. Diagn. 2010, 4, 53-65. [CrossRef]

11. West, K.A.; Clark, A.S.; Linnoila, I.R.; Yang, X.; Harris, C.; Belinsky, S.; Dennis, P.A.; Brognard, J.; Swain, S.M. Rapid Akt activation by nicotine and a tobacco carcinogen modulates the phenotype of normal human airway epithelial cells. J. Clin. Investig. 2003, 111, 81-90. [CrossRef] [PubMed]

12. Neasta, J.; Ben Hamida, S.; Yowell, Q.V.; Carnicella, S.; Ron, D. AKT Signaling Pathway in the Nucleus Accumbens Mediates Excessive Alcohol Drinking Behaviors. Boil. Psychiatry 2011, 70, 575-582. [CrossRef] [PubMed]

13. Surviladze, Z.; Sterk, R.T.; DeHaro, S.A.; Ozbun., M.A. Cellular entry of human papillomavirus type 16 involves activation of the phosphatidylinositol 3-kinase/Akt/mTOR pathway and inhibition of autophagy. J. Virol. 2013, 87, 2508-2517. [CrossRef] [PubMed]

14. Bellacosa, A.; Kumar, C.C.; Di Cristofano, A.; Testa, J.R. Activation of AKT Kinases in Cancer: Implications for Therapeutic Targeting. Advan. Cancer Res. 2005, 94, 29-86. 
15. Vivanco, I.; Sawyers, C.L. The phosphatidylinositol 3-Kinase-AKT pathway in human cancer. Nat. Rev. Cancer 2002, 2, 489-501. [CrossRef] [PubMed]

16. Baek, S.H.; Ko, J.H.; Lee, J.H.; Kim, C.; Lee, H.; Nam, D.; Lee, J.; Lee, S.G.; Yang, W.M.; Um, J.Y.; et al. Ginkgolic Acid Inhibits Invasion and Migration and TGF- $\beta$-Induced EMT of Lung Cancer Cells Through PI3K/Akt/mTOR Inactivation. J. Cell. Physiol. 2017, 232, 346-354. [CrossRef]

17. Mohan, C.D.; Srinivasa, V.; Rangappa, S.; Mervin, L.; Mohan, S.; Paricharak, S.; Baday, S.; Li, F.; Shanmugam, M.K.; Chinnathambi, A.; et al. Trisubstituted-Imidazoles Induce Apoptosis in Human Breast Cancer Cells by Targeting the Oncogenic PI3K/Akt/mTOR Signaling Pathway. PLoS ONE 2016, 11, e0153155. [CrossRef]

18. Singh, S.S.; Yap, W.N.; Arfuso, F.; Kar, S.; Wang, C.; Cai, W.; Dharmarajan, A.M.; Sethi, G.; Kumar, A.P. Targeting the PI3K/Akt signaling pathway in gastric carcinoma: A reality for personalized medicine? World J. Gastroenterol. 2015, 21, 12261-12273. [CrossRef]

19. Siveen, K.S.; Ahn, K.S.; Ong, T.H.; Shanmugam, M.K.; Li, F.; Yap, W.N.; Kumar, A.P.; Fong, C.W.; Tergaonkar, V.; Hui, K.M.; et al. $\gamma$-tocotrienol inhibits angiogenesis-dependent growth of human hepatocellular carcinoma through abrogation of AKT/mTOR pathway in an orthotopic mouse model. Oncotarget 2014, 5, 1897-1911. [CrossRef]

20. Kim, S.W.; Kim, S.M.; Bae, H.; Nam, D.; Lee, J.H.; Lee, S.G.; Shim, B.S.; Kim, S.H.; Ahn, K.S.; Choi, S.H.; et al. Embelin inhibits growth and induces apoptosis through the suppression of Akt/mTOR/S6K1 signaling cascades. Prostate 2013, 73, 296-305. [CrossRef]

21. Park, K.-R.; Nam, D.; Yun, H.-M.; Lee, S.-G.; Jang, H.-J.; Sethi, G.; Cho, S.K.; Ahn, K.S. $\beta$-Caryophyllene oxide inhibits growth and induces apoptosis through the suppression of PI3K/AKT/mTOR/S6K1 pathways and ROS-mediated MAPKs activation. Cancer Lett. 2011, 312, 178-188. [CrossRef] [PubMed]

22. Lee, J.H.; Kim, C.; Lee, S.-G.; Yang, W.M.; Um, J.-Y.; Sethi, G.; Ahn, K.S. Ophiopogonin D modulates multiple oncogenic signaling pathways, leading to suppression of proliferation and chemosensitization of human lung cancer cells. Phytomedicine 2018, 40, 165-175. [CrossRef] [PubMed]

23. Ko, J.-H.; Nam, D.; Um, J.-Y.; Jung, S.H.; Sethi, G.; Ahn, K.S. Bergamottin Suppresses Metastasis of Lung Cancer Cells through Abrogation of Diverse Oncogenic Signaling Cascades and Epithelial-to-Mesenchymal Transition. Molecules 2018, 23, 1601. [CrossRef] [PubMed]

24. Lee, H.; Baek, S.H.; Lee, J.H.; Kim, C.; Ko, J.H.; Lee, S.G.; Chinnathambi, A.; Alharbi, S.A.; Yang, W.M.; Um, J.Y.; et al. Isorhynchophylline, a Potent Plant Alkaloid, Induces Apoptotic and Anti-Metastatic Effects in Human Hepatocellular Carcinoma Cells through the Modulation of Diverse Cell Signaling Cascades. Int. J. Mol. Sci. 2017, 18, 1095. [CrossRef] [PubMed]

25. Kannaiyan, R.; Manu, K.A.; Chen, L.; Li, F.; Rajendran, P.; Subramaniam, A.; Lam, P.; Kumar, A.P.; Sethi, G. Celastrol inhibits tumor cell proliferation and promotes apoptosis through the activation of c-Jun N-terminal kinase and suppression of PI3 K/Akt signaling pathways. Apoptosis 2011, 16, 1028-1041. [CrossRef] [PubMed]

26. Sethi, G.; Ahn, K.S.; Sung, B.; Kunnumakkara, A.B.; Chaturvedi, M.M.; Aggarwal, B.B. SH-5, an AKT inhibitor potentiates apoptosis and inhibits invasion through the suppression of anti-apoptotic, proliferative and metastatic gene products regulated by IkB $\alpha$ kinase activation. Biochem. Pharmacol. 2008, 76, 1404-1416. [CrossRef] [PubMed]

27. Lorenzato, A.; Biolatti, M.; Delogu, G.; Capobianco, G.; Farace, C.; Dessole, S.; Cossu, A.G.M.; Tanda, F.; Madeddu, R.; Olivero, M.; et al. AKT activation drives the nuclear localization of CSE1L and a pro-oncogenic transcriptional activation in ovarian cancer cells. Exp. Cell Res. 2013, 319, 2627-2636. [CrossRef] [PubMed]

28. Rychahou, P.G.; Kang, J.; Gulhati, P.; Doan, H.Q.; Chen, L.A.; Xiao, S.-Y.; Chung, D.H.; Evers, B.M. Akt2 overexpression plays a critical role in the establishment of colorectal cancer metastasis. Proc. Natl. Acad. Sci. USA 2008, 105, 20315-20320. [CrossRef]

29. Cheng, J.Q.; Ruggeri, B.; Klein, W.M.; Sonoda, G.; Altomare, D.A.; Watson, D.K.; Testa, J.R. Amplification of AKT2 in human pancreatic cells and inhibition of AKT2 expression and tumorigenicity by antisense RNA. Proc. Natl. Acad. Sci. USA 1996, 93, 3636-3641. [CrossRef]

30. Iacovides, D.C.; Johnson, A.B.; Wang, N.; Boddapati, S.; Korkola, J.; Gray, J.W. Identification and Quantification of AKT Isoforms and Phosphoforms in Breast Cancer Using a Novel Nanofluidic Immunoassay. Mol. Cell. Proteom. 2013, 12, 3210-3220. [CrossRef]

31. Qiu, Z.-X.; Zhang, K.; Qiu, X.-S.; Zhou, M.; Li, W.-M. The Prognostic Value of Phosphorylated AKT Expression in Non-Small Cell Lung Cancer: A Meta-Analysis. PLoS ONE 2013, 8, e81451. [CrossRef] [PubMed] 
32. Roy, N.; Golla, R.; Kunnumakkara, A.; Kotoky, J. Specific Targeting of Akt Kinase Isoforms: Taking the Precise Path for Prevention and Treatment of Cancer. Curr. Drug Targets 2017, 18, 421-435. [CrossRef] [PubMed]

33. Han, C.-P.; Kok, L.-F.; Wang, P.-H.; Wu, T.S.; Tyan, Y.-S.; Cheng, Y.-W.; Lee, M.-Y.; Yang, S.-F. Scoring of p16INK4a immunohistochemistry based on independent nuclear staining alone can sufficiently distinguish between endocervical and endometrial adenocarcinomas in a tissue microarray study. Mod. Pathol. 2009, 22, 797-806. [CrossRef] [PubMed]

34. Remmele, W.; Schicketanz, K.-H. Immunohistochemical determination of estrogen and progesterone receptor content in human breast cancer. Pathol. Res. Pract. 1993, 189, 862-866. [CrossRef]

35. De Matos, L.L.; Stabenow, E.; Tavares, M.R.; Ferraz, A.R.; Capelozzi, V.L.; Pinhal, M.A.D.S. Immunohistochemistry quantification by a digital computer-assisted method compared to semiquantitative analysis. Clinics 2006, 61,417-424. [CrossRef] [PubMed]

36. Han, C.-P.; Lee, M.-Y.; Tzeng, S.-L.; Yao, C.-C.; Wang, P.-H.; Cheng, Y.-W.; Chen, S.-L.; Wu, T.S.; Tyan, Y.-S.; Kok, L.-F. Nuclear Receptor Interaction Protein (NRIP) expression assay using human tissue microarray and immunohistochemistry technology confirming nuclear localization. J. Exp. Clin. Cancer Res. 2008, $27,25$. [CrossRef]

37. Kamoi, S.; Aljuboury, M.I.; Akin, M.-R.; Silverberg, S.G. Immunohistochemical Staining in the Distinction Between Primary Endometrial and Endocervical Adenocarcinomas: Another Viewpoint. Int. J. Gynecol. Pathol. 2002, 21, 217-223. [CrossRef]

38. Cerami, E.; Gao, J.; Dogrusoz, U.; Gross, B.E.; Sumer, S.O.; Aksoy, B.A.; Jacobsen, A.; Byrne, C.J.; Heuer, M.L.; Larsson, E.; et al. The cBio Cancer Genomics Portal: An Open Platform for Exploring Multidimensional Cancer Genomics Data. Cancer Discov. 2012, 2, 401-404. [CrossRef]

39. Gao, J.; Dogrusoz, U.; Dresdner, G.; Gross, B.; Sun, Y.; Jacobsen, A.; Sinha, R.; Larsson, E.; Cerami, E.; Sander, C.; et al. Integrative analysis of complex cancer genomics and clinical profiles using the cBioPortal. Sci. Signal. 2013, 6, pl1. [CrossRef]

40. Schneider, C.A.; Rasband, W.S.; Eliceiri, K.W. NIH Image to ImageJ: 25 years of image analysis. Nat. Methods 2012, 9, 671-675. [CrossRef]

41. Franken, N.A.P.; Rodermond, H.M.; Stap, J.; Haveman, J.; Van Bree, C. Clonogenic assay of cells in vitro. Nat. Protoc. 2006, 1, 2315-2319. [CrossRef] [PubMed]

42. Rodriguez, L.G.; Wu, X.; Guan, J.L. Wound-healing assay. Methods Mol. Biol. 2005, 294, 23-29. [CrossRef] [PubMed]

43. Liang, C.-C.; Park, A.Y.; Guan, J.-L. In vitro scratch assay: A convenient and inexpensive method for analysis of cell migration in vitro. Nat. Protoc. 2007, 2, 329-333. [CrossRef] [PubMed]

44. Iamaroon, A.; Krisanaprakornkit, S. Overexpression and activation of Akt2 protein in oral squamous cell carcinoma. Oral Oncol. 2009, 45, e175-e179. [CrossRef] [PubMed]

45. Di Lorenzo, A.; Fernandez-Hernando, C.; Cirino, G.; Sessa, W.C. Akt1 is critical for acute inflammation and histamine-mediated vascular leakage. Proc. Natl. Acad. Sci. USA 2009, 106, 14552-14557. [CrossRef]

46. Yu, H.; Littlewood, T.; Bennett, M. Akt isoforms in vascular disease. Vasc. Pharmacol. 2015, 71, 57-64. [CrossRef]

47. Riggio, M.; Perrone, M.C.; Polo, M.L.; Rodriguez, M.J.; May, M.; Abba, M.; Lanari, C.; Novaro, V. AKT1 and AKT2 isoforms play distinct roles during breast cancer progression through the regulation of specific downstream proteins. Sci. Rep. 2017, 7, 44244. [CrossRef]

48. Watanabe, S.; Sato, K.; Okazaki, Y.; Tonogi, M.; Tanaka, Y.; Yamane, G.-Y. Activation of PI3K-AKT Pathway in Oral Epithelial Dysplasia and Early Cancer of Tongue. Bull. Tokyo Dent. Coll. 2009, 50, 125-133. [CrossRef]

49. Massarelli, E.; Liu, D.D.; Lee, J.J.; El-Naggar, A.K.; Muzio, L.L.; Staibano, S.; De Placido, S.; Myers, J.N.; Papadimitrakopoulou, V.A. Akt activation correlates with adverse outcome in tongue cancer. Cancer 2005, 104, 2430-2436. [CrossRef]

50. Tumino, R.; Vicario, G. Head and neck cancers: Oral cavity, pharynx, and larynx. Epidemiol. Prev. 2004, $28,28-33$.

51. Roy, N.K.; Bordoloi, D.; Monisha, J.; Singh, A.; Padmavathi, G.; Kunnumakkara, A.B. Isoform-specific Role of Akt Kinase in Cancer and its Selective Targeting by Potential Anticancer Natural Agents. Nat. Prod. J. 2017. Ahead of print. [CrossRef] 
52. Zhu, Z.; Yu, W.; Fu, X.; Sun, M.; Wei, Q.; Li, D.; Chen, H.; Xiang, J.; Li, H.; Zhang, Y.; et al. Phosphorylated AKT1 is associated with poor prognosis in esophageal squamous cell carcinoma. J. Exp. Clin. Cancer Res. 2015, 34, 2893. [CrossRef] [PubMed]

53. Yu, W.; Chu, L.; Zhao, K.; Chen, H.; Xiang, J.; Zhang, Y.; Li, H.; Zhao, W.; Sun, M.; Wei, Q.; et al. A nomogram based on phosphorylated AKT1 for predicting locoregional recurrence in patients with oesophageal squamous cell carcinoma. J. Cancer 2017, 8, 3755-3763. [CrossRef]

54. Miao, X.; Song, Y.; Lv, T.; Zhan, P.; Lv, Y.; Yuan, D. Expression and prognostic value of AKT2 in non-small cell lung cancer. Zhongguo Fei Ai Za Zhi 2011, 14, 396-399. [CrossRef] [PubMed]

55. Tsurutani, J.; Castillo, S.; Brognard, J.; Granville, C.A.; Zhang, C.; Gills, J.J.; Sayyah, J.; Dennis, P.A. Tobacco components stimulate Akt-dependent proliferation and NFKB-dependent survival in lung cancer cells. Carcinogenesis 2005, 26, 1182-1195. [CrossRef] [PubMed]

56. Sobus, S.L.; Warren, G.W. The biologic effects of cigarette smoke on cancer cells. Cancer 2014, 120, 3617-3626. [CrossRef] [PubMed]

57. Stopper, H.; Schmitt, E.; Gregor, C.; Mueller, S.O.; Fischer, W.H. Increased cell proliferation is associated with genomic instability: Elevated micronuclei frequencies in estradiol-treated human ovarian cancer cells. Mutagenesis 2003, 18, 243-247. [CrossRef] [PubMed]

58. Burdick, A.D.; Davis, J.W.; Liu, K.J.; Hudson, L.G.; Shi, H.; Monske, M.L.; Burchiel, S.W. Benzo(a)pyrene quinones increase cell proliferation, generate reactive oxygen species, and transactivate the epidermal growth factor receptor in breast epithelial cells. Cancer Res. 2003, 63, 7825-7833.

59. Kometani, T.; Yoshino, I.; Miura, N.; Okazaki, H.; Ohba, T.; Takenaka, T.; Shoji, F.; Yano, T.; Maehara, Y. Benzo[a]pyrene promotes proliferation of human lung cancer cells by accelerating the epidermal growth factor receptor signaling pathway. Cancer Lett. 2009, 278, 27-33. [CrossRef]

60. Wei, Y.; Zhao, L.; Chen, Y.; He, W.; Yang, J.; Geng, C.; Liu, T.; Chen, H.; Li, Y. Benzo[a]pyrene promotes gastric cancer cell proliferation and metastasis likely through the Aryl hydrocarbon receptor and ERK-dependent induction of MMP9 and c-myc. Int. J. Oncol. 2016, 49, 2055-2063. [CrossRef]

61. Grando, S.A. Connections of nicotine to cancer. Nat. Rev. Cancer 2014, 14, 419-429. [CrossRef] [PubMed]

62. Lee, H.-J.; Guo, H.-Y.; Lee, S.-K.; Jeon, B.-H.; Jun, C.-D.; Lee, S.-K.; Park, M.-H.; Kim, E.-C. Effects of nicotine on proliferation, cell cycle, and differentiation in immortalized and malignant oral keratinocytes. J. Oral Pathol. Med. 2005, 34, 436-443. [CrossRef] [PubMed]

63. Schaal, C.; Chellappan, S.P. Nicotine-mediated cell proliferation and tumor progression in smoking-related cancers. Mol. Cancer Res. 2014, 12, 14-23. [CrossRef] [PubMed]

64. Wang, C.; Xu, X.; Jin, H.; Liu, G. Nicotine may promote tongue squamous cell carcinoma progression by activating the Wnt/ $\beta$-catenin and Wnt/PCP signaling pathways. Oncol. Lett. 2017, 13, 3479-3486. [CrossRef] [PubMed]

65. Hollander, M.C.; Maier, C.R.; Hobbs, E.A.; Ashmore, A.R.; Linnoila, R.I.; Dennis, P.A. Akt1 deletion prevents lung tumorigenesis by mutant K-ras. Oncogene 2011, 30, 1812-1821. [CrossRef] [PubMed]

66. Hollander, M.; Zhou, X.; Maier, C.R.; Patterson, A.D.; Ding, X.; Dennis, P.A. A Cyp2a polymorphism predicts susceptibility to NNK-induced lung tumorigenesis in mice. Carcinogenesis 2011, 32, 1279-1284. [CrossRef] [PubMed]

67. Brait, M.; Munari, E.; Lebron, C.; Noordhuis, M.G.; Begum, S.; Michailidi, C.; Gonzalez-Roibon, N.; Maldonado, L.; Sen, T.; Guerrero-Preston, R.; et al. Genome-wide methylation profiling and the PI3K-AKT pathway analysis associated with smoking in urothelial cell carcinoma. Cell Cycle 2013, 12, 1058-1070. [CrossRef] [PubMed]

68. Kandel, E.S.; Skeen, J.; Majewski, N.; Di Cristofano, A.; Pandolfi, P.P.; Feliciano, C.S.; Gartel, A.; Hay, N. Activation of Akt/Protein Kinase B Overcomes a G2/M Cell Cycle Checkpoint Induced by DNA Damage. Mol. Cell. Boil. 2002, 22, 7831-7841. [CrossRef] [PubMed]

69. Lee, M.W.; Kim, D.S.; Lee, J.H.; Lee, B.S.; Lee, S.H.; Jung, H.L.; Sung, K.W.; Kim, H.T.; Yoo, K.H.; Koo, H.H. Roles of AKT1 and AKT2 in non-small cell lung cancer cell survival, growth, and migration. Cancer Sci. 2011, 102, 1822-1828. [CrossRef]

70. DiPaola, R.S. To arrest or not to G(2)-M Cell-cycle arrest: Commentary re: A. K. Tyagi et al., Silibinin strongly synergizes human prostate carcinoma DU145 cells to doxorubicin-induced growth inhibition, G(2)-M arrest, and apoptosis. Clin. Cancer Res. 2002, 8, 3512-3519, 2002. Clin. Cancer. Res. 2002, 8, 3311-3314. 
71. Barkley, L.R.; Santocanale, C.; Barkley, L. MicroRNA-29a regulates the benzo[a]pyrene dihydrodiol epoxide-induced DNA damage response through Cdc7 kinase in lung cancer cells. Oncogenesis 2013, 2, e57. [CrossRef] [PubMed]

72. Yu, S.-M.; Gweon, E.-J.; Chung, K.-W.; Kim, K.-H.; Cho, H.-S.; Kim, S.-J. Gallotannin regulates apoptosis and COX-2 expression via Akt and p38kinase pathway in human lung cancer cell line, A549. Anim. Cells Syst. 2012, 16, 366-375. [CrossRef]

73. Puliyappadamba, V.T.; Cheriyan, V.T.; Thulasidasan, A.K.T.; Bava, S.V.; Vinod, B.S.; Prabhu, P.R.; Varghese, R.; Bevin, A.; Venugopal, S.; Anto, R.J. Nicotine-induced survival signaling in lung cancer cells is dependent on their p53 status while its down-regulation by curcumin is independent. Mol. Cancer 2010, 9, 220. [CrossRef] [PubMed]

74. Joy, A.; Kapoor, M.; Georges, J.; Butler, L.; Chang, Y.; Li, C.; Crouch, A.; Smirnov, I.; Nakada, M.; Hepler, J.; et al. The role of AKT isoforms in glioblastoma: AKT3 delays tumor progression. J. Neurooncol. 2016, 130, 43-52. [CrossRef] [PubMed]

75. Mure, H.; Matsuzaki, K.; Kitazato, K.T.; Mizobuchi, Y.; Kuwayama, K.; Kageji, T.; Nagahiro, S. Akt2 and Akt3 play a pivotal role in malignant gliomas. Neuro. Oncol. 2010, 12, 221-232. [CrossRef]

76. Endersby, R.; Zhu, X.; Hay, N.; Ellison, D.W.; Baker, S.J. Non-redundant functions for Akt isoforms in astrocyte growth and gliomagenesis in an orthotopic transplantation model. Cancer Res. 2011, 71, 4106-4116. [CrossRef]

77. Zitzmann, K.; Vlotides, G.; Brand, S.; Lahm, H.; Spottl, G.; Göke, B.; Auernhammer, C.J. Perifosine-mediated Akt inhibition in neuroendocrine tumor cells: Role of specific Akt isoforms. Endocr. Relat. Cancer 2012, 19, 423-434. [CrossRef]

78. Watkins, A. The Role of Akt Isoforms in BCR-ABL Induced Chronic Myeloid Leukemia. Ph.D. Thesis, Thomas Jefferson University, Philadelphia, PA, USA, 2012.

79. Hung, C.-S.; Peng, Y.-J.; Wei, P.-L.; Lee, C.-H.; Su, H.-Y.; Ho, Y.-S.; Lin, S.-Y.; Wu, C.-H.; Chang, Y.-J. The $\alpha 9$ Nicotinic Acetylcholine Receptor is the Key Mediator in Nicotine-enhanced Cancer Metastasis in Breast Cancer Cells. J. Exp. Clin. Med. 2011, 3, 283-292. [CrossRef]

80. Wei, P.-L.; Kuo, L.-J.; Huang, M.-T.; Ting, W.-C.; Ho, Y.-S.; Wang, W.; An, J.; Chang, Y.-J. Nicotine Enhances Colon Cancer Cell Migration by Induction of Fibronectin. Ann. Surg. Oncol. 2011, 18, 1782-1790. [CrossRef]

81. Di Cello, F.; Flowers, V.L.; Li, H.; Vecchio-Pagan, B.; Gordon, B.; Harbom, K.; Shin, J.; Beaty, R.; Wang, W.; Brayton, C.; et al. Cigarette smoke induces epithelial to mesenchymal transition and increases the metastatic ability of breast cancer cells. Mol. Cancer. 2013, 12, 90. [CrossRef]

82. Warren, G.W.; Singh, A.K.; Gw, W.; Ak, S. Nicotine and lung cancer. J. Carcinog. 2013, 12, 1. [CrossRef] [PubMed]

83. Zhang, J.; Chang, L.; Jin, H.; Xia, Y.; Wang, L.; He, W.; Li, W.; Chen, H. Benzopyrene promotes lung cancer A549 cell migration and invasion through up-regulating cytokine IL8 and chemokines CCL2 and CCL3 expression. Exp. Boil. Med. 2016, 241, 1516-1523. [CrossRef] [PubMed]

84. Hecht, S.S.; Szabo, E. Fifty Years of Tobacco Carcinogenesis Research: From Mechanisms to Early Detection and Prevention of Lung Cancer. Cancer Prev. Res. 2014, 7, 1-8. [CrossRef] [PubMed]

85. Bulj, Z.; Duchi, S.; Bevilacqua, A.; Gherardi, A.; Dozza, B.; Piccinini, F.; Adalgisa Mariani, G.; Lucarelli, E.; Giannini, S.; Donati, D.; et al. Protein kinase B/AKT isoform 2 drives migration of human mesenchymal stem cells. Int. J. Oncol. 2013, 42, 118-126. [CrossRef] [PubMed]

86. Sugatani, T.; Hruska, K.A. Akt1/Akt2 and mammalian target of rapamycin/Bim play critical roles in osteoclast differentiation and survival, respectively, whereas Akt is dispensable for cell survival in isolated osteoclast precursors. J. Biol. Chem. 2005, 280, 3583-3589. [CrossRef] [PubMed]

87. Calamito, M.; Juntilla, M.M.; Thomas, M.; Northrup, D.L.; Rathmell, J.; Birnbaum, M.J.; Koretzky, G.; Allman, D. Akt1 and Akt2 promote peripheral B-cell maturation and survival. Blood 2010, 115, 4043-4050. [CrossRef] [PubMed]

88. Haggblad Sahlberg, S.; Mortensen, A.C.; Haglof, J.; Engskog, M.K.; Arvidsson, T.; Pettersson, C.; Glimelius, B.; Stenerlow, B.; Nestor, M. Different functions of AKT1 and AKT2 in molecular pathways, cell migration and metabolism in colon cancer cells. Int. J. Oncol. 2017, 50, 5-14. [CrossRef] [PubMed]

89. Gately, S. The Contributions of Cyclooxygenase-2 to Tumor Angiogenesis. Cancer Metastasis Rev. 2000, 19, 19-27. [CrossRef] [PubMed] 
90. St-Germain, M.-̇̀; Gagnon, V.; Parent, S.; Asselin, E. Regulation of COX-2 protein expression by Akt in endometrial cancer cells is mediated through NF-кB/IкB pathway. Mol. Cancer 2004, 3, 7. [CrossRef]

91. Uddin, S.; Ahmed, M.; Hussain, A.; Assad, L.; Bavi, P.; Munkarah, A.; Al-Dayel, F.; Al-Kuraya, K.S.; Al-Dayel, F.; Al-Kuraya, K.S. Cyclooxygenase-2 inhibition inhibits PI3K/AKT kinase activity in epithelial ovarian cancer. Int. J. Cancer 2010, 126, 382-394. [CrossRef]

92. Williams, C.S.; Mann, M.; Dubois, R.N. The role of cyclooxygenases in inflammation, cancer, and development. Oncogene 1999, 18, 7908-7916. [CrossRef] [PubMed]

93. Tang, D.-W.; Lin, S.-C.; Chang, K.-W.; Chi, C.-W.; Chang, C.-S.; Liu, T.-Y. Elevated expression of cyclooxygenase (COX)-2 in oral squamous cell carcinoma-Evidence for COX-2 induction by areca quid ingredients in oral keratinocytes. J. Oral Pathol. Med. 2003, 32, 522-529. [CrossRef] [PubMed]

94. Pannone, G.; Sanguedolce, F.; De Maria, S.; Farina, E.; Muzio, L.L.; Serpico, R.; Emanuelli, M.; Rubini, C.; De Rosa, G.; Staibano, S.; et al. Cyclooxygenase Isozymes in Oral Squamous Cell Carcinoma: A Real-Time RT-PCR Study with Clinic Pathological Correlations. Int. J. Immunopathol. Pharmacol. 2007, 20, 317-324. [CrossRef] [PubMed]

95. Søland, T.M.; Husvik, C.; Koppang, H.S.; Boysen, M.; Sandvik, L.; Clausen, O.P.F.; Christoffersen, T.; Bryne, M. A study of phosphorylated ERK1/2 and COX-2 in early stage (T1-T2) oral squamous cell carcinomas. J. Oral Pathol. Med. 2008, 37, 535-542. [CrossRef] [PubMed]

96. Danielsson, K.; Ebrahimi, M.; Wahlin, Y.B.; Nylander, K.; Boldrup, L. Increased levels of COX-2 in oral lichen planus supports an autoimmune cause of the disease. J. Eur. Acad. Dermatol. Venereol. 2012, 26, 1415-1419. [CrossRef]

97. Rakesh, N.; Iyengar, A.; Majumdar, K.; Vidya, G.S.; Shantha Kumar, S.S. Quantitative Evaluation of Tumour-Associated Tissue Eosinophilia and Cyclo-oxegenase-2 Gene in Oral Cancer Patients with Assessment of Long Term Outcomes. Pathol. Oncol. Res. 2016, 22, 385-392. [CrossRef] [PubMed]

98. Sawhney, M.; Rohatgi, N.; Kaur, J.; Shishodia, S.; Sethi, G.; Gupta, S.D.; Deo, S.V.S.; Shukla, N.K.; Aggarwal, B.B.; Ralhan, R. Expression of NF-kB parallels COX-2 expression in oral precancer and cancer: Association with smokeless tobacco. Int. J. Cancer 2007, 120, 2545-2556. [CrossRef]

99. Salimi, M.; Esfahani, M.; Habibzadeh, N.; Aslani, H.R.; Amanzadeh, A.; Esfandiary, M.; Sedaghati, B.; Bidgoli, S.A.; Ghahremani, M.H. Change in Nicotine-Induced VEGF, PGE2 AND COX-2 Expression Following COX Inhibition in Human Oral Squamous Cancer. J. Environ. Pathol. Toxicol. Oncol. 2012, 31, 349-356. [CrossRef]

100. Moazeni-Roodi, A.; Allameh, A.; Harirchi, I.; Motiee-Langroudi, M.; Garajei, A. Studies on the Contribution of Cox-2 Expression in the Progression of Oral Squamous Cell Carcinoma and H-Ras Activation. Pathol. Oncol. Res. 2017, 23, 355-360. [CrossRef]

101. Sappayatosok, K.; Maneerat, Y.; Swasdison, S.; Viriyavejakul, P.; Dhanuthai, K.; Zwang, J.; Chaisri, U. Expression of pro-inflammatory protein, iNOS, VEGF and COX-2 in oral squamous cell carcinoma (OSCC), relationship with angiogenesis and their clinico-pathological correlation. Med. Oral Patol. Oral Cir. Bucal 2009, 14, 319-324.

102. Hong, Z.-H.; Shao, F.; Zhu, G.-G.; Su, T. Expression of NF-kB and COX-2 in tongue squamous cell carcinoma. Shanghai Kou Qiang Yi Xue 2010, 19, 335-338. [PubMed]

103. Morita, Y.; Hata, K.; Nakanishi, M.; Nishisho, T.; Yura, Y.; Yoneda, T. Cyclooxygenase-2 promotes tumor lymphangiogenesis and lymph node metastasis in oral squamous cell carcinoma. Int. J. Oncol. 2012, 41, 885-892. [CrossRef] [PubMed]

104. Wang, Y.H.; Wu, M.W.; Yang, A.K.; Zhang, W.D.; Sun, J.; Liu, T.R.; Chen, Y.F. COX-2 Gene increases tongue cancer cell proliferation and invasion through VEGF-C pathway. Med. Oncol. 2011, 28 (Supp. 1), S360-S366. [CrossRef] [PubMed]

105. Li, T.-J.; Cui, J. COX-2, MMP-7 expression in oral lichen planus and oral squamous cell carcinoma. Asian Pac. J. Trop. Med. 2013, 6, 640-643. [CrossRef]

106. Kono, M.; Watanabe, M.; Abukawa, H.; Hasegawa, O.; Satomi, T.; Chikazu, D. Cyclo-Oxygenase-2 Expression Is Associated with Vascular Endothelial Growth Factor C Expression and Lymph Node Metastasis in Oral Squamous Cell Carcinoma. J. Oral Maxillofac. Surg. 2013, 71, 1694-1702. [CrossRef] 
107. Morita, Y.; Morita, N.; Hata, K.; Nakanishi, M.; Kimoto, N.; Omata, T.; Nakamura, Y.; Yoneda, T. Cyclooxygenase-2 expression is associated with vascular endothelial growth factor-c and lymph node metastasis in human oral tongue cancer. Oral Sur. Oral Med. Oral Pathol. Oral Radiol. 2014, 117, 502-510. [CrossRef] [PubMed]

108. Segawa, E.; Sakurai, K.; Kishimoto, H.; Takaoka, K.; Noguchi, K.; Hashitani, S.; Hirota, S.; Urade, M. Expression of cyclooxygenase- 2 and DNA topoisomerase II $\alpha$ in precancerous and cancerous lesions of the oral mucosa. Oral Oncol. 2008, 44, 664-671. [CrossRef]

109. Prado, S.M.D.; Cedrún, J.L.L.; Rey, R.L.; Villaamil, V.M.; Álvarez García, A.; Ayerbes, M.V.; Aparicio, L.A. Evaluation of COX-2, EGFR, and p53 as biomarkers of non-dysplastic oral leukoplakias. Exp. Mol. Pathol. 2010, 89, 197-203. [CrossRef]

110. Pontes, H.A.; Pontes, F.S.; Fonseca, F.P.; de Carvalho, P.L.; Pereira, E.M.; de Abreu, M.C.; de Freitas Silva, B.S.; dos Santos Pinto, D., Jr. Nuclear factor kB and cyclooxygenase-2 immunoexpression in oral dysplasia and oral squamous cell carcinoma. Ann. Diagn. Pathol. 2013, 17, 45-50. [CrossRef]

111. Byatnal, A.A.; Byatnal, A.; Sen, S.; Guddattu, V.; Solomon, M.C. Cyclooxygenase-2-An Imperative Prognostic Biomarker in Oral Squamous Cell Carcinoma-An Immunohistochemical Study. Pathol. Oncol. Res. 2015, 21, 1123-1131. [CrossRef]

112. Mittal, M.; Kapoor, V.; Mohanti, B.K.; Das, S.N. Functional variants of COX-2 and risk of tobacco-related oral squamous cell carcinoma in high-risk Asian Indians. Oral Oncol. 2010, 46, 622-626. [CrossRef]

113. Li, D.; Hao, S.-H.; Sun, Y.; Hu, C.-M.; Ma, Z.-H.; Wang, Z.M.; Liu, J.; Liu, H.B.; Ye, M.; Zhang, Y.F.; et al. Functional Polymorphisms inCOX-2Gene Are Correlated with the Risk of Oral Cancer. BioMed Res. Int. 2015, 2015, 1-12. [CrossRef] [PubMed]

114. Nasry, W.H.S.; Rodriguez-Lecompte, J.C.; Martin, C.K. Role of COX-2/PGE2 Mediated Inflammation in Oral Squamous Cell Carcinoma. Cancers 2018, 10, 348. [CrossRef] [PubMed]

115. Sobolewski, C.; Cerella, C.; Dicato, M.; Ghibelli, L.; Diederich, M. The Role of Cyclooxygenase-2 in Cell Proliferation and Cell Death in Human Malignancies. Int. J. Cell Boil. 2010, 2010, 1-21. [CrossRef] [PubMed]

116. Chen, W.; Bai, L.; Wang, X.; Xu, S.; Belinsky, S.A.; Lin, Y. Acquired activation of the Akt/cyclooxygenase-2/Mcl-1 pathway renders lung cancer cells resistant to apoptosis. Mol. Pharmacol. 2010, 77, 416-423. [CrossRef] [PubMed]

117. Attoub, S.; Arafat, K.; Hammadi, N.K.; Mester, J.; Gaben, A.-M. Akt2 knock-down reveals its contribution to human lung cancer cell proliferation, growth, motility, invasion and endothelial cell tube formation. Sci. Rep. 2015, 5, 12759. [CrossRef] [PubMed]

118. Fu, M.; Wang, C.; Li, Z.; Sakamaki, T.; Pestell, R.G. Minireview: Cyclin D1: Normal and Abnormal Functions. Endocrinol. 2004, 145, 5439-5447. [CrossRef] [PubMed]

119. Chang, F.; Lee, J.T.; Navolanic, P.M.; Steelman, L.S.; Shelton, J.G.; Blalock, W.L.; Franklin, R.A.; McCubrey, J.A.; Blalock, W. Involvement of PI3K/Akt pathway in cell cycle progression, apoptosis, and neoplastic transformation: A target for cancer chemotherapy. Leuk. 2003, 17, 590-603. [CrossRef] [PubMed]

120. Grabinski, N.; Bartkowiak, K.; Grupp, K.; Brandt, B.; Pantel, K.; Jücker, M. Distinct functional roles of Akt isoforms for proliferation, survival, migration and EGF-mediated signalling in lung cancer derived disseminated tumor cells. Cell. Signal. 2011, 23, 1952-1960. [CrossRef] [PubMed]

121. Song, G.; Ouyang, G.; Bao, S. The activation of Akt/PKB signaling pathway and cell survival. J. Cell. Mol. Med. 2005, 9, 59-71. [CrossRef] [PubMed]

122. Green, B.D.; Jabbour, A.M.; Sandow, J.J.; Riffkin, C.D.; Masouras, D.; Daunt, C.P.; Salmanidis, M.; Brumatti, G.; Hemmings, B.A.; Guthridge, M.A.; et al. Akt1 is the principal Akt isoform regulating apoptosis in limiting cytokine concentrations. Cell Death Differ. 2013, 20, 1341-1349. [CrossRef] [PubMed]

123. Chen, X.; Duan, N.; Zhang, C.; Zhang, W. Survivin and Tumorigenesis: Molecular Mechanisms and Therapeutic Strategies. J. Cancer 2016, 7, 314-323. [CrossRef] [PubMed]

(C) 2019 by the authors. Licensee MDPI, Basel, Switzerland. This article is an open access article distributed under the terms and conditions of the Creative Commons Attribution (CC BY) license (http://creativecommons.org/licenses/by/4.0/). 